\title{
Overview of the geophysical studies in the Dead Sea coastal area related to evaporite karst and recent sinkhole development
}

\author{
Michael G. Ezersky ${ }^{1 *}$, Anatoly Legchenko², Lev Eppelbaum ${ }^{3}$, and Abdallah Al-Zoubi \\ ${ }^{1}$ Geotec Engineering \& Environmental Geophysics Ltd.,18b, Ruzhanski Str., PO Box 25031, Rishon Lezion 7502501, Israel \\ ${ }^{2}$ Institute of Research for Development, University Grenoble Alpes, IGE, Grenoble, France, UGA - IGE, CS 40700, 38058 Grenoble Cedex 9, France \\ ${ }^{3}$ Department of Geosciences, Raimond and Beverly Sackler Faculty of Exact Sciences, Tel Aviv University, Ramat Aviv, 6997801, Tel Aviv, Israel \\ ${ }^{4}$ Engineering Faculty, Al-Balqa Applied University, Salt, 19117 Jordan
}

\begin{abstract}
Since the early 80 s, a progressively increasing number of sinkholes appeared along the Dead Sea coastal line. It has been found that their appearance is strongly correlating with the lowering of the Dead Sea level taking place with the rate of approximately $1 \mathrm{~m} / \mathrm{yr}$. Location of areas affected by sinkhole development corresponds to location of the salt formation deposited during the latest Pleistocene, when the Lake Lisan receded to later become the Dead Sea. Water flowing to the Dead Sea from adjacent and underlying aquifers dissolves salt and creates caverns that cause ground subsidence and consequent formation of sinkholes. Before subsidence, these caverns are not visible on the surface but can be investigated with surface geophysical methods. For that, we applied Surface Nuclear Magnetic Resonance (SNMR), Transient Electromagnetic (TEM) Seismic refraction and reflection, Multichannel Analysis of Surface waves (MASW), microgravity and magnetic surveys and their combinations. Our geophysical results allowed us to locate the salt formation and to detect caverns in salt thus contributing to better understanding sinkhole development mechanisms. Comparison of sinkhole appearance along the western DS shore derived from the recent database (2017) shows that predictions made on the base of geophysical data (2005-2008) are now confirmed thus demonstrating efficiency of our study. In this paper, we briefly present a summary of up to date knowledge of the geology and hydrogeology of Dead Sea basin, of the physical properties of the salt rock and the most popular models explaining mechanisms of sinkhole development. We also share our experience gained during geophysical studies carried out in the framework of national and international research projects in this area for the last 20 years.
\end{abstract}

Keywords: Dead Sea, evaporate karst, geophysics, sinkholes

Received 29 October 2016; Revised 4 June 2017; Accepted 4 June 2017

Citation: $\quad$ Ezersky M.G., Legchenko A., Eppelbaum L. and Al-Zoubi A., 2017. Overview of the geophysical studies in the Dead Sea coastal area related to evaporite karst and recent sinkhole development. International Journal of Speleology, 46 (2), 277-302. Tampa, FL (USA) ISSN 0392-6672 https://doi.org/10.5038/1827-806X.46.2.2087

\section{INTRODUCTION}

Thousands of sinkholes have been formed during the last 30 years along the Dead Sea (DS) coastal areas in Israel (Abelson et al., 2006; Yechieli et al., 2016; DS sinkhole database 1998-2016) and Jordan (Closson \& Abou Karaki, 2009; Abou Karaki et al., 2016; Abueladas, 2016, pers. comm.) (See Fig. 1).

Generally, the sinkhole susceptibility problem is widely known in limestone karst, associated with collapse or subsidence into subsurface cavities (e.g., Klimchouk, 2005; De Waele et al., 2009; Frumkin et al., 2009a; Parise et al., 2009, Gutiérrez et al., 2014). Sinkhole clusters in carbonate karst terrains commonly develop and modify over long geological periods. Although methodologies for the detection of sinkholes and other karst features in carbonate rocks (generally limestone) have received much attention worldwide (Arandelovich, 1969; Milanović, 1981, 2000; Beck \& Herring, 2001; Beck, 2003) these methodologies need to be adapted, or new methods developed, for the unique environment of evaporite deposits along the Dead Sea coast in Jordan and Israel. The main differences between the karst areas in carbonate rocks and the sites with unconsolidated sediments in the Dead Sea region are the following: (1) subsurface dissolution of the salty rock is observed quite often in response to changes of environmental conditions; and (2) very high salinity groundwater is present.

The first feature is commonly attributed to sinkholes formed in evaporite areas, where dissolution 


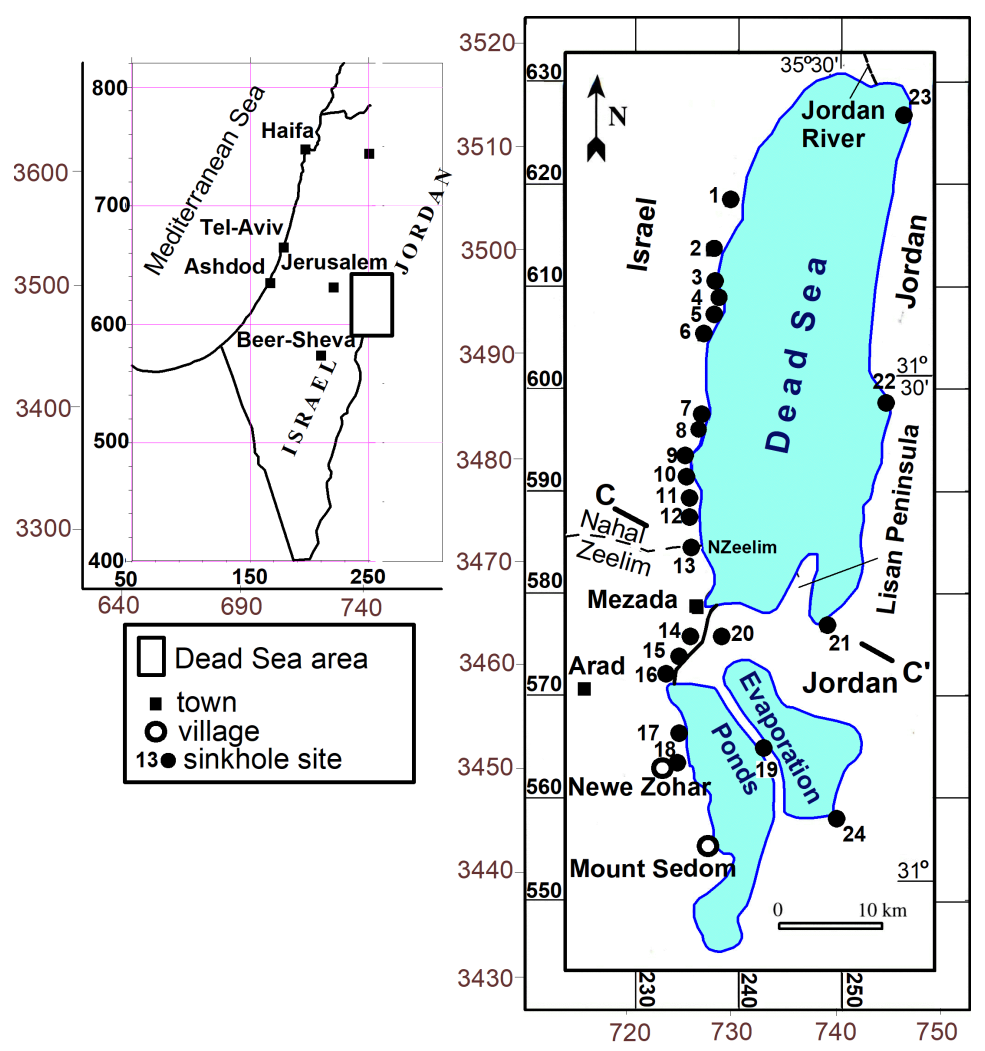

Fig. 1. Sinkhole sites along Dead Sea shore: 1) Zikim; 2) Avenat; 3) N.Qane;

4) Samar; 5) N. Deragot; 6) Mineral Beach; 7) Ein Gedi and Nahal Arugot;

8) Yesha; 9) Mazor; 10) Nahal Hever north; 11) Nahal Hever south; 12) Asa'el; 13) Nahal Zeelim; 14) Rahaf; 15) Lynch Straight; 16) Mor; 17) Ein Boqeq;

18) Newe Zohar; 19) Dam-2; 20) Lisan; 21) Ghor Al-Haditha; 22) Wadi Mejib;

23) Suweimeh; 24) unnamed; (20-24 - after Closson and Abu Karaki, 2009).

CC' - line of the generalized geological section (the coordinates in the frame are new Israel Mercator grid in $\mathrm{km}$, the outer coordinates are Universal Transverse Mercator grid, in km).

rates are one to three orders of magnitude faster compared with limestone (Reuter \& Stoyan; 1993, Gutiérrez et al., 2008). Salt is very soluble when coming in contact with a slightly saline (undersaturated) circulating groundwater. Therefore, sinkhole hazard related to dissolution of subsurface salt by such water and collapse of overlying material may also be relatively rapid, from days to some weeks (Frumkin, 1995; Van Sambeek, 1996; Stiller et al., 2016).

The second condition is that Dead Sea groundwater is essentially more saturated in salt than normal groundwater, thus slightly slowing down the dissolution process (months, years) and allowing the observation of changes in geophysical properties of the subsurface on a human life scale.

Salt outcrops around DS are rare and produce typical vadose karst morphologies characterized by localized sinkholes, blind valleys and underground streams (e.g., Frumkin, 1994; Burthens et al., 2009; De Waele et al., 2009). Geomorphic changes, including sinkhole development, can be extremely rapid particularly in areas where human activities alter groundwater circulation (Lucha et al., 2008). Gutiérrez et al. (2008) propose a phased approach for the identification, investigation, prediction, and mitigation of sinkholes in evaporite terrains. The protective measures were proposed by Taqieddin et al. (2000) and Yechieli et al. (2006). Probabilistic sinkhole modeling for hazard assessment and sinkhole susceptibility mapping were attempted for evaporite karst (Galve et al., 2009a, b).

Sinkholes are surface manifestations of subsurface dissolution, internal erosion, and deformation, commonly hidden from direct observation and from most subaerial geomorphological study methods (Gutiérrez et al., 2014).

A strong contrast in the physical properties between different geological formations in the Dead Sea coast requires the use of surface geophysical methods (Frumkin et al., 2011). Different geophysical methods have been tested for the various aspects of sinkhole hazard assessment. Moreover, TEM method allows to determine the DS water salinity and to map it through the sinkhole hazardous areas (Ezersky \& Frumkin, 2017). Therefore, geophysical methods can facilitate sinkhole susceptibility assessment in the DS coastal areas both in Israel and Jordan. In the framework of DS sinkhole studies numerous geophysical methodologies were developed and applied to examine the evaporite karst phenomenon. A list of geophysical methods used for the study of the DS sinkhole problem by the authors and different researchers is collected in Table 1.

In this paper, we intend to summarize the available experience and to compare predictions of sinkhole expansion throughout the DS basin made by different authors. We also tried to compare these predictions with the recent geologicalgeophysical observations. We hope that such an analysis will produce a better understanding of the phenomenon, which is particularly important at present, when construction of a channel between the Red and Dead Seas (Beyth, 2007) is being definitely decided.

We anticipate discussing the presence of a salt layer both in western (Israel) and eastern sides of the DS shores. For instance, such analysis in the Ghor Al-Haditha area (eastern DS side) will be based on an integrated analysis of all available geophysical data.

\section{GEOLOGY AND HYDROGEOLOGY IN THE DEAD SEA AREA}

\section{Generalities}

The Dead Sea (DS) is probably, the best-known example of a hypersaline lake (34.2\% salinity in 2010), and it is also the deepest salt lake in the world (Goetz, 1986; Ben Avraham, 2001). Generally, a hypersaline lake is a landlocked body of water that contains significant concentrations of sodium chloride or other mineral salts, with saline levels surpassing that of ocean water (3.5\%; i.e., $35 \mathrm{~g} / 1)$. The DS is the deepest subaerial point on Earth, located in an extremely arid environment with an annual precipitation of 50-100 mm.

The DS lies within a transform that looks like a depression, $150 \mathrm{~km}$ long and $15-17 \mathrm{~km}$ wide in its center, divided into two sub-basins (Fig. 1). The southern subaerial sub-basin is dry; it contains 
Table 1. Geophysical method used for sinkhole studies.

\begin{tabular}{|c|c|c|c|}
\hline Method's name & Physical properties to be measured & Capability of detection & References \\
\hline Seismic refraction & $\begin{array}{c}\text { Seismic velocity of longitudinal waves }\left(V_{p}\right) \\
\text { in solid salt layers }(2,900-4,500 \mathrm{~m} / \mathrm{s}) \text { that is } \\
\text { considerably higher than sedimentary } \\
\text { overburden }(2,100-2,700 \mathrm{~m} / \mathrm{s})\end{array}$ & $\begin{array}{l}\text { Salt elastic properties and salt } \\
\text { delineation }\end{array}$ & $\begin{array}{l}\text { Ezersky, 2006; } \\
\text { Ezersky et al., } 2010\end{array}$ \\
\hline $\begin{array}{l}\text { Multichannel } \\
\text { analysis of surface } \\
\text { waves (MASW) }\end{array}$ & Seismic velocity of shear $(\mathrm{S})$ waves $\left(V_{s}\right)$ & $\begin{array}{l}\text { Salt shear velocities and } \\
\text { modulus to estimate salt } \\
\text { porosity and karstification }\end{array}$ & $\begin{array}{l}\text { Bodet et al., 2010; } \\
\text { Ezersky et al., } 2013\end{array}$ \\
\hline $\begin{array}{l}\text { P-wave seismic } \\
\text { reflection }\end{array}$ & $\begin{array}{c}\text { Study of the deep (down to } 200 \mathrm{~m} \text { ) subsurface } \\
\text { structure, detection of sub-horizontal interfaces } \\
\text { and faults }\end{array}$ & $\begin{array}{l}\text { Detection of salt layer within } \\
\text { sediments, faults etc. }\end{array}$ & $\begin{array}{l}\text { Keydar et al., 2010, } \\
\text { 2012, 2013, Ezersky } \\
\text { \& Frumkin, } 2013\end{array}$ \\
\hline $\begin{array}{l}\text { S-wave seismic } \\
\text { reflection }\end{array}$ & $\begin{array}{l}\text { Study of the shallow (down to } 100 \mathrm{~m} \text { ) subsurface } \\
\text { structure, detection of sub-horizontal interfaces } \\
\text { and faults }\end{array}$ & $\begin{array}{l}\text { Detection of salt layer within } \\
\text { sediments, faults etc. }\end{array}$ & $\begin{array}{l}\text { Krawczyk et al., } \\
\text { 2015; Polom et al., } \\
2016 \\
\end{array}$ \\
\hline $\begin{array}{l}\text { Transient } \\
\text { Electromagnetic } \\
\text { (TEM, TDEM) }\end{array}$ & $\begin{array}{l}\text { Low resistivity of aquifer formations }(1 \Omega \mathrm{m} \text { to } \\
0.5 \Omega \mathrm{m} \text { ) in contrast to the surrounding sediments } \\
\text { (more than to } 10 \Omega \mathrm{m} \text { ) }\end{array}$ & $\begin{array}{l}\text { accurate location of the top of } \\
\text { the aquifer and mapping water } \\
\text { salinity variations }\end{array}$ & $\begin{array}{c}\text { Goldman et al., 1991; } \\
\text { Kafri et al., 1997; } \\
\text { Ezersky et al., 2011; } \\
\text { Ezersky \& } \\
\text { Frumkin, } 2017\end{array}$ \\
\hline $\begin{array}{l}\text { Electric Resistivity } \\
\text { Tomography (ERT) }\end{array}$ & DC resistivity in subsurface & $\begin{array}{l}\text { search anomalously high } \\
\text { resistivity }\end{array}$ & $\begin{array}{l}\text { Ezersky, 2008; Al- } \\
\text { Zoubi et al., 2007 }\end{array}$ \\
\hline $\begin{array}{l}\text { Magnetic Resonance } \\
\text { Sounding (MRS) } \\
\text { or Surface Nuclear } \\
\text { Magnetic Resonance } \\
\text { (SNMR) + 3D-SNMR }\end{array}$ & $\begin{array}{l}\text { Water in the karst voids and water in the } \\
\text { surrounding sediments produce nuclear magnetic } \\
\text { resonance signal with different relaxation time } \\
\text { (less than } 150 \mathrm{~ms} \text { in sediments and more than } \\
600 \mathrm{~ms} \text { in karst }\end{array}$ & $\begin{array}{l}\text { Detection of water filled voids } \\
\text { and estimate the volume of } \\
\text { water in karstic caves }\end{array}$ & $\begin{array}{l}\text { Legchenko et al., } \\
\text { 2006a; Legchenko, } \\
2013\end{array}$ \\
\hline MRS + TEM & $\begin{array}{l}\text { Bulk resistivity, water content }(\mathrm{W}), \text { hydraulic } \\
\text { conductivity }(\mathrm{K}) \text { and relaxation time }\left(T_{1}\right) \text { allows } \\
\text { resolve equivalency }\end{array}$ & $\begin{array}{l}\text { Identification of the subsurface } \\
\text { lithology }\end{array}$ & $\begin{array}{l}\text { Legchenko et al., } \\
\text { 2008b; } 2009\end{array}$ \\
\hline MRS+MASW & $\mathrm{K}$ and $V_{s}$ and & $\begin{array}{l}\text { Estimating of the salt } \\
\text { hydraulic conductivity }\end{array}$ & $\begin{array}{c}\text { Ezersky and } \\
\text { Legchenko, } 2014\end{array}$ \\
\hline $\begin{array}{l}\text { Ground penetrating } \\
\text { radar (GPR) }\end{array}$ & $\begin{array}{l}\text { Structure of most shallow (10-15 m) sediments } \\
\text { located over karstified unconsolidated salt }\end{array}$ & $\begin{array}{l}\text { Detection of density deficit } \\
\text { caused by cavities moving } \\
\text { upward (stoping) }\end{array}$ & $\begin{array}{l}\text { Frumkin et al., } \\
\text { 2009b; } 2011\end{array}$ \\
\hline Microgravity & $\begin{array}{c}\text { Detection of gravity anomalies against strong } \\
\text { noise background }\end{array}$ & $\begin{array}{l}\text { Detection of caverns, } \\
\text { estimation of their depth and } \\
\text { volume }\end{array}$ & $\begin{array}{l}\text { El-Isa et al., 1995; } \\
\text { Rybakov et al., 2001; } \\
\text { Eppelbaum et al., } \\
\text { 2007; 2008; 2010; } \\
\text { 2015a, b; Ezersky et } \\
\text { al., 2013 b }\end{array}$ \\
\hline $\begin{array}{l}\text { Gravimetry }+ \\
\text { radar differential } \\
\text { interferometry }\end{array}$ & ground subsidence caused by deficit of mass & $\begin{array}{l}\text { potentially hazardous areas } \\
\text { because of underground } \\
\text { cavities }\end{array}$ & $\begin{array}{l}\text { Closson et al., 2003; } \\
\text { 2005, Nof et al., } 2013\end{array}$ \\
\hline $\begin{array}{l}\text { Photogrammetry + } \\
\text { satellite }\end{array}$ & $\begin{array}{l}\text { Ground reflectance, diachronic analysis, } \\
\text { spatial co-occurrence }\end{array}$ & Areas prone to sinkholes & $\begin{array}{l}\text { Al-Halbouni et al., } \\
2017\end{array}$ \\
\hline $\begin{array}{l}\text { Nano seismicity and } \\
\text { microseismic } \\
\text { activity }\end{array}$ & $\begin{array}{l}\text { Measuring of vibrations produced by falling stones } \\
\text { in the underground cavities }\end{array}$ & $\begin{array}{l}\text { Pre-collapse identification } \\
\text { of sinkhole activity in } \\
\text { unconsolidated media }\end{array}$ & $\begin{array}{l}\text { Wust-Bloch \& Joswig, } \\
\quad 2006 \\
\text { Abelson et al., } 2013\end{array}$ \\
\hline
\end{tabular}

commercial artificial evaporation ponds (EP) and reaches a maximum elevation of about $405 \mathrm{~m}$ below mean sea level (b.m.s.1.). At the deepest point in the northern sub-basin, the maximum water depth is $\sim 300 \mathrm{~m}$ ( 700 m b.m.s.1.).

The Dead Sea level has been dropping since the $1960 \mathrm{~s}$, at a mean rate of $1 \mathrm{~m} / \mathrm{yr}$ for the last decade, reaching $431 \mathrm{~m}$ b.m.s.1. in January 2017 (Fig. 2). Lowering of the groundwater level caused the development of sinkholes thus threatening economic development in this region.

\section{Tectonics}

The DS depression is an actively subsiding N-S elongated basin formed along the Dead Sea-Jordan transform-plate boundary. It is a classic example of a pull-apart basin. The pull-apart is associated with NW-SE compression and NE-SW tensile stress (Fig. 3a) (Garfunkel, 1997). Numerous faults have been detected throughout the DS area (Fig. 3b) mainly trending N-S and NW-SE (Al-Zoubi \& ten Brink, 2001; Shamir, 2006).

The basin is still tectonically active. The central part of the DS subsides along normal faults forming the graben area. The subsidence is conditioned by the pull-apart causing the $\mathrm{W}$-E divergence of the marginal faults (Garfunkel, 1997).

The major structural feature of the Western DS shore is the western border of the DS basin where several large normal faults exist. Considering a typical deep W-E vertical section (Fig. 4) through the Lisan Peninsula (along line C-C' in Fig. 1b) (Garfunkel, 1981; Closson, 2005; Ezersky et al., 2014) one can see that the $3-6 \mathrm{~km}$ space between the bordering faults is composed of clastic Quaternary sediments that do not transfer tectonic stresses (see also Shalev \& Lyakhovsky, 2012, p. 166). This is especially understandable taking into account the W-E divergence of the Dead Sea Transform boundaries (Wdowinski et al., 2004). 


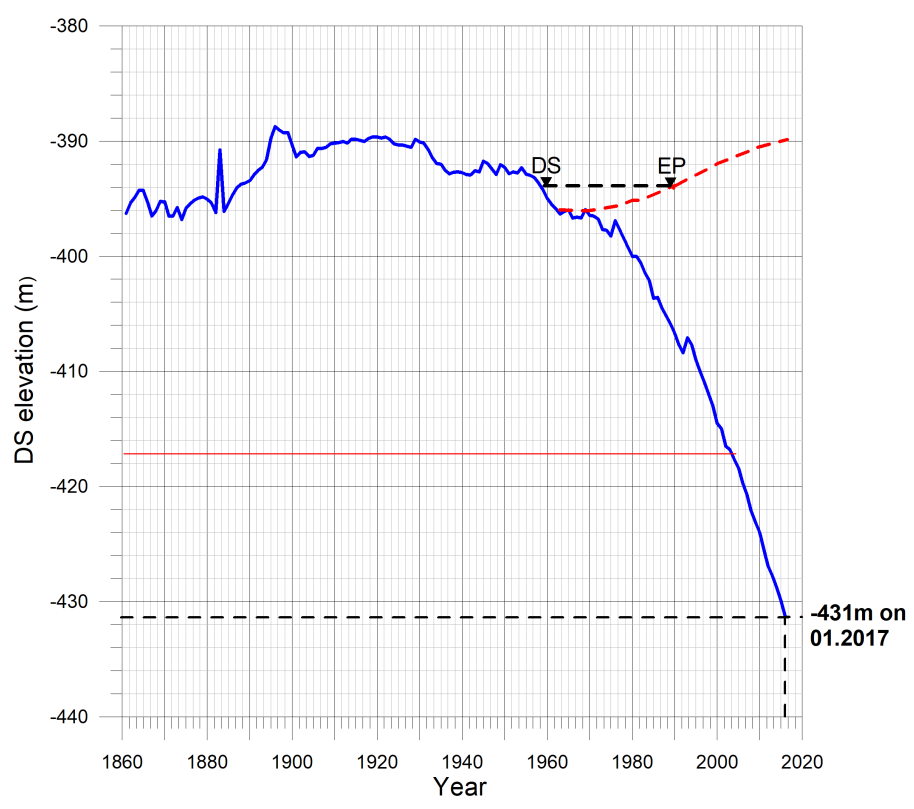

Fig. 2. Variations of the DS level during last 157 years. Thick solid line, DS (northern basin); red dashed line and EP (evaporation ponds, southern basin); red thin line - salt top elevation at the Nahal Hever South (NHS) site (data of the Geological Survey of Israel).

\section{Shallow geological section}

The survey areas are located between the DS shoreline and the western and eastern borders of the DS rift within the graben area. A general geological W-E section through the DS (along C-C' line) is shown in Fig. 5 (see Fig. 1b for location). The coastal plain between the fault escarpment and the DS shores consists mainly of Quaternary clastics (marl, sand, and gravel) deposited in fan deltas and debris flows, with some intercalations of lacustrine sediments (silt, clay, gypsum, halite, and aragonite) mainly of the Lisan Formation (Begin et al., 1974) and younger Holocene sediments, named the Ze'elim Formation (Yechieli et al., 1995).

The typical geological section of the DS western side (Israel) based on 80-90 $\mathrm{m}$ deep boreholes (Yechieli et al., 2004) is composed of alluvial fan sediments to a depth of 20-50 m. Salt layers have a thickness of 6-30 $\mathrm{m}$ and are located at depths of 20-50 m (top). Salt is usually sandwiched between marl layers from below and from above, especially when approaching the DS shoreline. The salt edge to the west of the DS is often in contact with the sandy-gravel sediments (Yechieli et al., 2004). Thus, salt and clayey sediments divide sand and gravel formations into several subaquifers (Yechieli et al., 2006).

The Eastern part of the DS section (Jordan) has been specified in accordance with El-Isa et al. (1995) unpublished report widely cited in the geological literature (Taqieddin et al., 2000; Closson, 2005; Frumkin et al., 2011; Al-Halbouni et al., 2017). This section was discovered by boreholes down to $50 \mathrm{~m}$ and did not cross the salt layer, which was proposed by Taqieddin et al. (2000).

\section{DS soils and their properties}

The theoretical, empiric and model studies aimed to investigate features and regularities of sinkhole formation require a comprehensive knowledge of

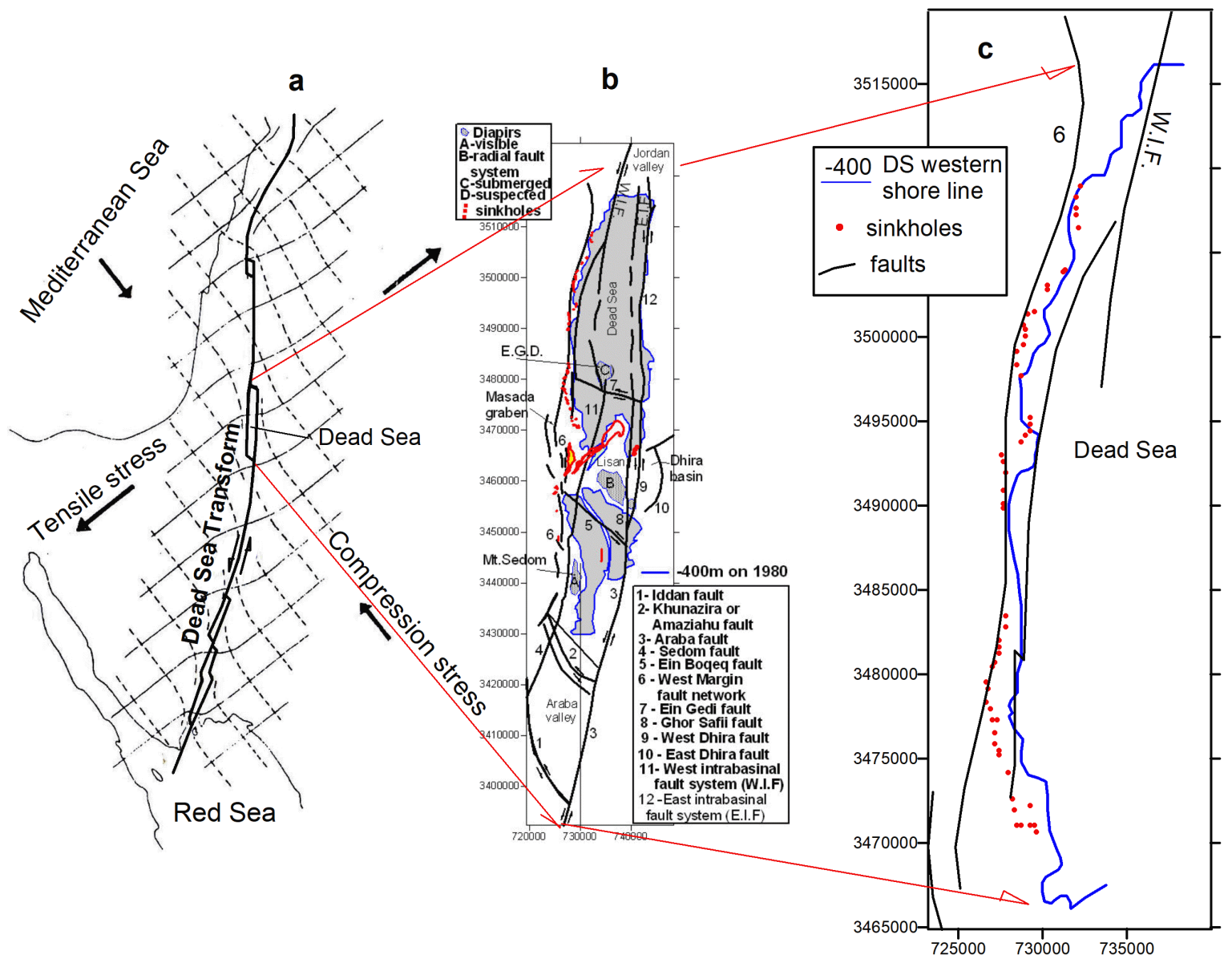

Fig. 3. Dead Sea tectonic setting: a) Pull-apart basin with stress acting in regional scale (Garfunkel, 1981); b) Faults through the DS area (Ben-Avraham, 1997); c) Western faults (gray lines), DS shoreline at $-400 \mathrm{~m}$ lake level (blue) and sinkholes (red) in increased scale. (Permission of Elsevier, Ezersky \& Frumkin, 2013). 


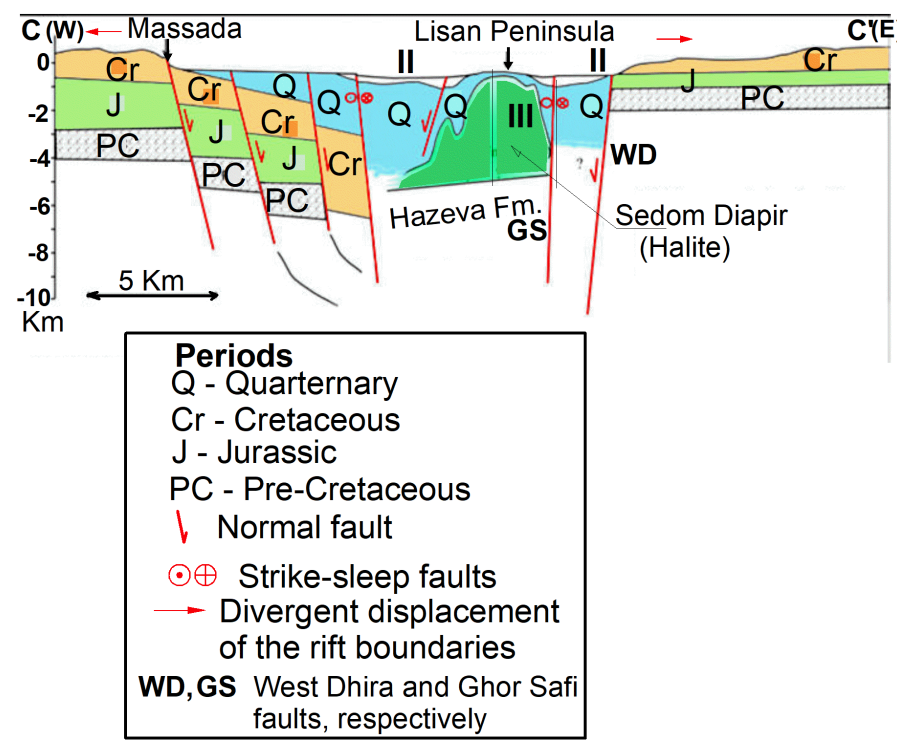

Fig. 4. Deep geological section along approximately C-C' line in Fig. 1 (according to Garfunkel, 1981).

soil and salt properties presenting the sinkhole environment (Maimon et al., 2005; Shalev \& Lyakhovsky, 2012; Ezersky \& Frumkin, 2017). We have studied the soil and salt properties both in situ and laboratory conditions. Arkin \& Gilat (2000) have selected three types of sinkholes: (1) gravel holes occurring in alluvial fans, (2) mud holes developing in the mudflats between fans, and (3) a combination of both types that are formed at the front of young alluvial fans where they overlap mud flats. Therefore, two types of lithology and salt cores were studied in laboratory and in-situ conditions to reveal geotechnical and geophysical properties of DS soils. Two boreholes MN-5E and EB-3E, of clayey and sandy-gravel lithology, respectively, were drilled in the Mineral Beach and Ein Boqeq sites (Fig. 6). $M N-5 E$ borehole (Fig. 6a) was drilled in the northern DS basin in the margin of an alluvial fan near Mineral Beach SPA. This vertical profile consists mainly of fine-grained sediments, silts with a little clay (named after Frydman et al. (2008, 2014) lime carbonates) with few inter-layers of gravels. $\underline{E B-3 E}$ borehole was drilled in the alluvial fan of the Ein Boqeq site (Fig. 6b). The profile consists mainly of coarse clastic sandy-gravel sediments (Livne, 2012). Note the profile is typical for the DS fans. A similar coarse sandy-gravel lithology is reported by Taqieddin et al. (2000) on the Jordanian shore. Hydrogeological conditions of these sites have been studied using ground water salinity monitoring (Yechieli et al., 2007). We suggest that the drilled boreholes are presentative for the similar lithology and salt layers along the DS shores in Israel and Jordan (El-Isa et al., 1995; Taqieddin et al., 2000; Charrach et al., 2007; Khlaifata et al., 2010; Livne, 2012; Ezersky, 2013; Ezersky \& Livne, 2013; Ezersky \& Goretsky, 2014; Frydman et al., 2014).

For instance, boreholes HS-2 and HS-3 (Figs. 6c, d, respectively) drilled in the Nahal Hever south site in 2001 , crossed the same lithology presented by alluvial sandy-gravel sediments, marl and salt. In the HS-3 borehole located $40 \mathrm{~m}$ south of the HS-2 borehole, a mud layer was discovered which replaced dissolved salt located at the same depth (Yechieli et al., 2004, Ezersky et al., 2009).

Thus, this study has enabled us to reveal geotechnical and geophysical properties of the abovementioned soils and inter-relationships between them (Livne, 2012; Ezersky, 2013; Ezersky \& Livne, 2013). We have used the following methods:

1) The laboratory testing of sandy-gravel sediments was carried out in the Ben-Gurion University (BGU) geotechnical laboratory by Livne (2012) in accordance to the methodology suggested by Frydman et al. (2008). Lime carbonates were tested in the Building and Infrastructure Testing Lab. Ltd. and results are presented in Ezersky (2013). The laboratory testing included determination of density, water content, Atterberg limits and USGS classification. Clayey samples of undisturbed structure were studied additionally by the Bender element to measure shear wave velocity $\left(V_{s}\right)$ in consolidated brinesaturated conditions. Unconfined compressive strength $q_{u}$ of those samples was measured after testing by Bender Element. Unconsolidated undrained triaxial compression tests were carried out on naturally wet samples located above the water table.

2) Boreholes were studied using Standard Penetration Test (SPT) and seismic downhole (DH) survey. Transient Electromagnetic (TEM) soundings were carried out near every borehole. Samples of undisturbed structure were selected from boreholes of silty lithology and other samples were obtained from sampling spoons.

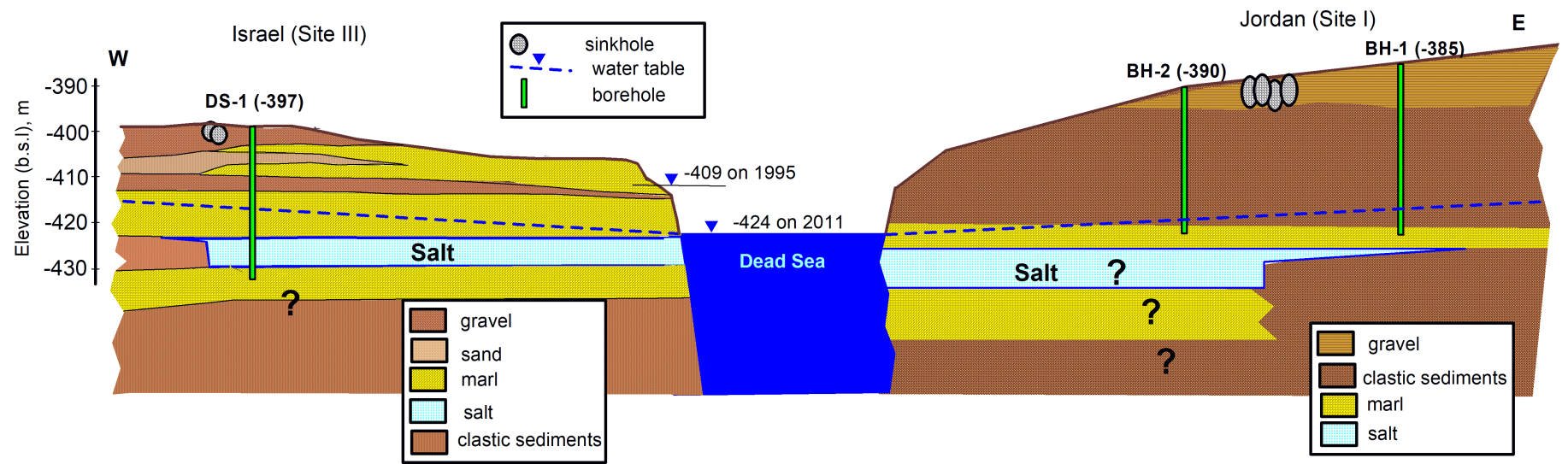

Fig. 5. Generalized geological W-E section (along line C-C' in Fig. 1) through the southern part of the Dead Sea (according to El-Isa et al., 1995). 

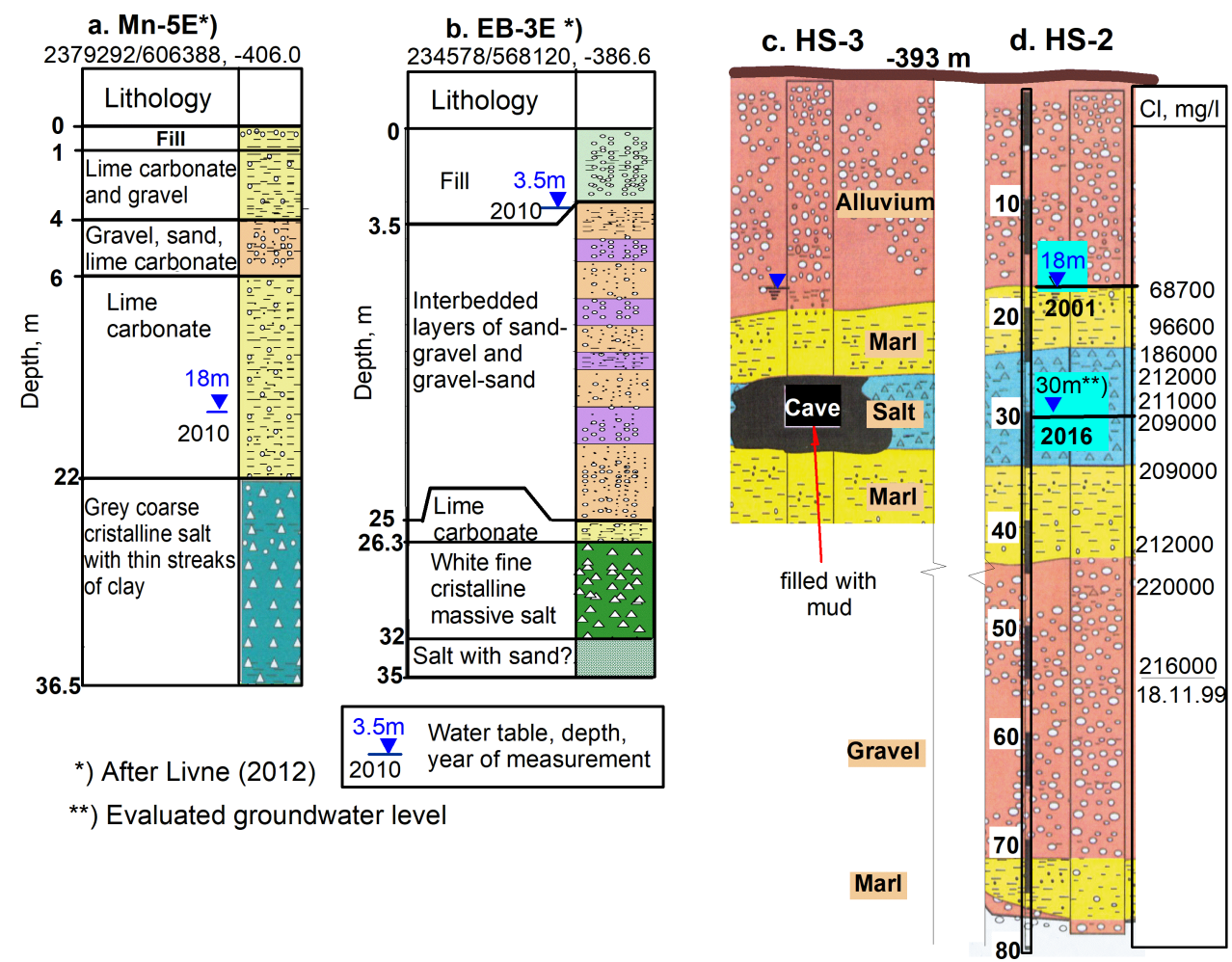

Fig. 6. Lithological sections of boreholes a) MN-5E from the Mineral Beach site; b) EB-3E from the Ein Boqeq site and c, d) boreholes HS-3 and HS-2 (40 m apart) from the Nahal Hever South area (see Fig. 1 for location) [a, b) Permission of Elsevier, Ezersky \& Goretsky, 2013; c) Permission of Springer, Ezersky et al., 2009].

\section{Laboratory study}

Properties of soils measured in laboratory and in the field conditions are presented in Table 2. The consistency of lime carbonate can be defined as firm - stiff (based on SPT values of range 4-16 and unconfined strength $50-220 \mathrm{kPa}$ ). The lime carbonate sediments are typically comprised of laminated, clay to silt size clastic sediments (predominantly calcite), and authigenic aragonite and gypsum. The clastic detrital material was brought into the basin by seasonal floods. The DS lime carbonate sediment is made up of about $95 \%$ calcite, with the other $5 \%$ being aragonite, quartz and gypsum.

Note, also, that carbonate soils of the western DS area are typical also (with some reserves) for its eastern (Jordanian) shores where both coarse sandy gravel sediments (Taqieddin et al. 2000) and mud flats composed of lime carbonates (Khlaifata et al., 2010) are presented.

Lime carbonates demonstrate one more peculiarity, e.g., very low cation exchange capacity (CEC) (Khlaifata et al., 2010) that allows using the TEM resistivity method for determining the porosity of both sands and DS mud as suggested by Kafri \& Goldman (2005). Note also that significant difference of $V_{s}$ allows distinguishing different lithologies along the DS coastal areas.

\section{DS salt and water}

The salt of the coastal DS area is composed of 10,200-10,800-year-old layers (Yechieli et al., 1995). The halite layer was deposited in Early Holocene during the development of extremely arid conditions in the shrinking phase between the Lisan Lake and the present Dead Sea (Stein et al., 2010). The halite commonly appears as rock salt. The salt was formed within the Dead Sea area, and its boundary extends west of the existing pool (Ezersky et al., 2013b).

The salt unit is located below the groundwater table at depths of 20-50 m from the surface. The DS salt is characterized by unit weights considerably lower than those usually discussed in the literature, and by the correspondingly different mechanical properties (Frydman et al., 2014). The unit reaches 4-7 $\mathrm{m}$ in thickness at the marginal sites of the lake and thickens up to $30 \mathrm{~m}$ toward the deeper lake environment (Stein et al., 2010). Holocene sandy-gravel sediments and lime carbonates overlie the salt unit. The lime carbonate sediments comprise laminated clay- to siltsized, clastic sediments (calcite), authigenic aragonite, and gypsum (Charrach et al., 2007). The DS salt layers are very conductive hydraulically and watersaturated with DS brine of very high salinity with total dissolved solids [TDS] of $340 \mathrm{~g} / 1$ (up to $380 \mathrm{~g} / 1$ in the southern basin) (Yechieli, 2000, Yechieli et al., 2001). Geophysical properties of the DS salt in laboratory and in-situ conditions are presented in Table 2 (Ezersky, 2006; Ezersky et al., 2013a, c; Ezersky \& Goretsky, 2014). Mechanical properties of the Dead Sea salt can be found in Frydman et al. (2008, 2014).

The chemical composition of the Dead Sea solution and groundwater in boreholes is presented in Table 3.

Average density of the DS brine is $1,230 \mathrm{~kg} / \mathrm{m}^{3}$ in the northern basin and $1,240 \mathrm{~kg} / \mathrm{m}^{3}$ in the EPs. Note that the composition of DS brine generally differs from other saline lakes in its high concentration of magnesium and calcium (Hammer, 1986). However, it is very similar to the water composition of the hypersaline Lake Assal located in Djibouti (Horn of Africa), which has a salinity level of $34.8 \%$ (i.e., 
Table 2. Soil, salt and DS brine properties.

\begin{tabular}{|c|c|c|c|c|c|}
\hline Lithology & Sandy-gravel s & diments (SG) & Lime carbo & ates (LC) & Comments \\
\hline Soils & Laboratory* & Field & Laboratory** & Field & \\
\hline Classification & $\begin{array}{l}\mathrm{SW}, \mathrm{SM}, \mathrm{SP}- \\
\text { gravels a }\end{array}$ & $\begin{array}{l}\text { oarse clastic } \\
\text { d sands }\end{array}$ & $\mathrm{CL}$ - lime $\mathrm{C}$ & bonates & after USCS \\
\hline Fine content $\%$ & & & $94-99$ & & $(<0.074 \mathrm{~mm})$ \\
\hline Water content, \% & $15-25$ & & $40-48$ & & \\
\hline Unit weigth, $\gamma_{t}, \mathrm{kN} / \mathrm{m}^{3}$ & $16.6-23$ & & $7-15$ & & dry \\
\hline Liquid limits (LL) & & & $31-44$ & & \\
\hline Plasticity index (PI) & & & $8-18$ & & \\
\hline $\begin{array}{l}\text { Consolidated undrained triaxial } \\
\text { strength }(\mathrm{CU})\end{array}$ & & & & & \\
\hline Friction angle, $\varphi^{0}$ & & & 34 & & \\
\hline Cohesion $\mathrm{C}, \mathrm{kPa}$ & & & 0 & & \\
\hline $\begin{array}{l}\text { Unconsolidatedundrained triaxial } \\
\text { strength (UU) }\end{array}$ & & & & & \\
\hline Friction angle, $\varphi^{0}$ & & & 1 & & \\
\hline Cohesion $\mathrm{C}, \mathrm{kPa}$ & & & 19 & & \\
\hline$V_{s}, \mathrm{~m} / \mathrm{s}$ & & $300-650$ & $90 / 350$ & $120-250$ & Bender test at $0 / 500 \mathrm{kPa}$ \\
\hline $\begin{array}{l}\text { SPT (Standard Penetration Test), } \\
\text { Blow } / 30 \mathrm{~cm}\end{array}$ & & $16-50$ & & $5-25$ & \\
\hline Bulk resistivity $\rho_{x}, \Omega m$ & & $0.3-0.5$ & & $0.2-0.3$ & \\
\hline Pore fluid density, DS brine, $\mathrm{kg} / \mathrm{m}^{3}$ & $1,230 / 1,240$ & & & & Northern/southern basin \\
\hline Salt & & & & & \\
\hline$V_{p}, \mathrm{~m} / \mathrm{s}$ & $3,700-4,460$ & $2,900-4,250$ & & & \\
\hline$V_{s}, \mathrm{~m} / \mathrm{s}$ & $1,900-2,620$ & $750-1,800$ & & & \\
\hline Bulk resistivity $\rho_{x}, \Omega m$ & $2-100$ & $0.5-2.0$ & & & \\
\hline DS water & & & & & \\
\hline total dissolved solids [TDS], g/1 & $340 / 380$ & & & & Northern/southern basin \\
\hline$V_{p}, \mathrm{~m} / \mathrm{s}$ & 1,800 & 1,820 & & & \\
\hline
\end{tabular}

* Tests were carried out in the Ben Gurion University of Negev (BGU) geotechnical laboratory by Livne (2012)

** Tests were carried out in the Building and Infrastructure Testing Lab. Ltd (Haifa) by Goretsky

Both soils were tested in accordance to Friedman et al. (2008) for saline water saturated samples

Table 3. Chemical composition of ground water from two wells, DS and EP.

\begin{tabular}{|c|c|c|c|c|c|c|c|c|c|c|c|c|}
\hline Well & Depth & $\mathrm{Na}, \mathrm{g} / \mathbf{1}$ & $\begin{array}{l}\mathrm{K}, \\
\mathrm{g} / 1\end{array}$ & $\mathrm{Ca}, \mathrm{g} / 1$ & $\mathrm{Mg}, \mathrm{g} / 1$ & $\begin{array}{l}\mathrm{Sr}, \\
\mathrm{g} / 1\end{array}$ & $\mathrm{Cl}, \mathrm{g} / \mathrm{1}$ & $\mathrm{SO}_{4}$ & $\mathrm{Br}, \mathrm{g} / 1$ & $\begin{array}{c}\text { TDS } \\
\text { g/1 }\end{array}$ & $\begin{array}{c}\mathrm{NaCl}, \\
\mathrm{g} / 1\end{array}$ & $\begin{array}{l}\text { Other } \\
\text { solids }\end{array}$ \\
\hline $\mathrm{Mn} 2 *$ & 20 & 67.0 & 5.3 & 9.9 & 28.0 & 0.15 & 205.4 & 1.20 & 3.70 & 320.65 & 272.4 & 48.25 \\
\hline $\operatorname{Mn} 2^{*}$ & 25 & 75.0 & 4.3 & 11.15 & 22.6 & 0.18 & 200.0 & 1.10 & 3.20 & 317.53 & 275.0 & 42.53 \\
\hline $\mathrm{Mn} 2 *$ & 30 & 75.7 & 4.6 & 11.30 & 22.8 & 0.18 & 202.0 & 1.10 & 3.20 & 320.88 & 277.7 & 43.18 \\
\hline EB2* & 20 & 26.0 & 8.4 & 19.9 & 50.8 & 0.36 & 229.8 & & 5.63 & 340.89 & 255.8 & 85.09 \\
\hline EB2* & 28 & 25.7 & 8.4 & 19.8 & 50.4 & 0.36 & 230.7 & & 5.65 & 341.11 & 256.5 & 84.61 \\
\hline EB2* & 40 & 30.6 & 6.7 & 18.1 & 47.6 & 0.32 & 223.9 & & 5.43 & 332.65 & 254.5 & 78.15 \\
\hline $\mathrm{DS}^{* *}$ & & 40.1 & 7.65 & 17.2 & 44.0 & & 224.9 & 0.45 & 5.30 & 339.6 & 265.0 & 74.6 \\
\hline $\mathrm{EP}^{* *}$ & & 16.7 & 11.1 & 25.2 & 62.3 & & 258.9 & 0.29 & 7.47 & 381.96 & 275.6 & 106.36 \\
\hline
\end{tabular}

*Yechieli et al. (2004); **Yechieli (2000)

10 times saltier than the ocean water). The drop in the DS level has to lead to the migration of unsaturated (in relation to $\mathrm{Cl}^{-}$) groundwater into the coastal area, accelerating the dissolution process at the zone in which groundwater comes in contact with the salt layer (Yechieli et al., 2006; Frumkin et al., 2011).

\section{GENERAL KNOWLEDGE ON SINKHOLE FORMATION MECHANISMS}

\section{Piping model}

At the first stage of DS sinkhole investigations a hypothesis of washing out mechanism was suggested (Arkin \& Gilat, 2000). Three main types of sinkholes have been recognized. Gravel holes occurring in alluvial fans, mud holes occurring in the intervening bays of clay deposits between fans and a combination of both types at the front of young alluvial fans where they overlap mud flats. Fossil, relict sinkholes have been observed in the channels of some old alluvial fans. Sinkhole development is directly related to the regression of the Dead Sea and the corresponding lowering of the regional water table. Respectively, mechanism of sinkhole formation was suggested for two types of sinkholes.

Gravel hole development.

Stage 1. Subsurface erosion begins above turbulent flow in gravel bed. A hollow and pipe develops upward. Fines are washed out and larger particles compacted. 
Stage 2. Circular fractures develop at the surface.

Stage 3. Sudden collapse of upper layer. Fine material washed out at base of pipe and coarse material compacted.

\section{Mudhole development}

Stage 1. Subsurface erosion starts in gravel or salt crystal layers where the laminated flows become turbulent. A hollow and pipe forms upward. Subsidence starts at the surface.

Stage 2. Subsidence continues with appearing concentric fractures at the surface forming a typical funnel shape. Fines are washed out at the base of the pipe.

Stage 3. Walls at the surface collapse and increase the diameter of the hole. As the process continues several holes may coalesce.

Frumkin \& Raz (2001) have shown that in western DS side underground water streams bringing washed out fines to the DS are not energetic enough. However, Ezersky et al. (2009), have shown that this mechanism can be reliable in some specific cases. Recently, AlHalboni et al. (2017) suggested a similar mechanism for sinkhole formation in Ghor Al-Haditha, presuming that a massive saline clay layer underlies the alluvial sandy-gravel sediments.

\section{"Structural" model}

Later, two main hypotheses were suggested that provide an explanation for the location of sinkholes in the DS area. The first hypothesis ("structural" one) is based on a visual correspondence between sinkhole lineaments and western and eastern fault escarpments (Abelson et al., 2003, 2006; Closson, 2005; Closson \& Karaki, 2009). Based on this similarity, a structural control was assumed and a corresponding numerical model of fault-induced sinkholes was developed (Shalev et al., 2006). Abelson et al. (2003) suggested that sinkholes tend to develop along faults, which serve as preferential hydraulic pathways, bringing confined aggressive water upwards to come in contact with salt. Closson (2005) considered a similar mechanism for the Jordanian Dead Sea coast.

A main question arises that numerous faults are widely distributed through the DS coastal area (e.g., Garfunkel, 1981; Garfunkel et al., 1997), whereas sinkholes are usually developed in a single narrow strip 50-100 m wide, roughly parallel to the DS shore.

\section{"Salt edge" model}

The other hypothesis proposes that sinkholes form along a dissolution front (buried salt edge) over a tilted salt layer (western edge in Israel and eastern edge in Jordan). The term "salt edge" was suggested by Jenyon (1986). Visually, DS sinkholes develop along slightly tortuous lines that on aerial photography may look like a series of lineament segments. In accordance to seismic refraction mapping this tortuous line corresponds to salt border variations (Ezersky, 2006). The spatial pattern of the sinkhole development along the salt edge was observed repeatedly (with small variations) in all studied sites in Israel and in the Ghor Al-Haditha area (Jordan). It enabled us to conclude that the salt edge is a major factor controlling sinkhole formation (Legchenko et al., 2008a; Ezersky et al., 2010). This hypothesis requires the existence of shallow salt layers on both sides of the DS.

This hypothesis is based on seismic refraction surveys carried out mainly along the western DS shore (Ezersky, 2006; Ezersky \& Legchenko, 2008; Ezersky et al., 2010; Frumkin et al., 2011) and in Ghor AlHaditha (El-Isa et al., 1995; Abueladas \& Al-Zoubi, 2004, Dhemaied, 2007). Numerous boreholes drilled in the western DS side have confirmed the presence of a salt layer. Along the Jordanian side, boreholes were drilled delivering fresh water and there are no direct evidence of salt.

\section{Combined "structural" and "salt edge" model}

Ezersky \& Frumkin (2013) reconciled these two models of the Dead Sea sinkhole genesis: salt edge and structural ones. In accordance with this consideration the authors suggested (based on analysis of the seismic reflection studies) that the salt edge was formed either in contact with normal faults or alternatively, in contact with wadi sediments. At the same time, sinkholes were formed at the dissolution front (salt edge). It explains why sinkhole lineaments are sometimes parallel to faults and sometimes deflect from them following the salt edge instead (Fig. 3c). It can distinguish sinkholes by kind of dissolving groundwater either coming via fault (like Mineral Beach sinkholes) or from wadies (like Ein Gedi, Arugot).

Both hypotheses consider salt karstification as a main mechanism of sinkhole formation. The working hypothesis suggests that brackish groundwater circulation (coming from either faults or from wadies) dissolves salt by a gradual increase of salt emptiness and permeability and formation of caverns at the zone adjoining the fault or salt edge. Thus, sinkholes are caused by the collapse of soil to large caverns in a buried salt layer.

The drop in the Dead Sea level slightly induces changes in the brackish - saline water interface thus creating the contact between the salt layer and relatively fresher (but yet very saline) water (Frumkin \& Raz, 2001; Yechieli et al., 2006). Ezersky \& Frumkin (2017) has shown that DS sandy-gravel aquifer with bulk resistivity of $0.55-1.0 \Omega m$ contains in pores brine with $110-50 \mathrm{~g} / 1$ chloride $(50-22 \%$ of saturation, respectively), e.g., it keeps potential to dissolve up to 114-174 g/1 salt and therefore it is aggressive with respect to salt layers. It is important to underline that when the DS level was high, the salt layer was relatively protected by very saline water. Thus, the appearance of sinkholes depends upon the location of the salt layer and the brackish - saline water interface. Legchenko et al. (2008c) have suggested that slow dissolution of salt has caused the formation of preexisting caverns in the salt formation, which caused the sinkhole development. This process was triggered by progressive lowering of the groundwater level with a time delay imposed by mechanical properties and the thickness of covering rocks. 
Based on our geophysical studies we have suggested a model of sinkhole formation. In the Dead Sea area, the head of the overlying aquifer has diminished dramatically during the last decades due to the fall of sea level, promoting increased artesian flow and rapid dissolution. Salt dissolution may take place a short or long period before any signs are evident at the surface (Fig. 7a). The sinkholes commonly develop along the salt edge (Ezersky, 2006; Legchenko et al., 2008c; Ezersky \& Frumkin, 2013). The salt is dissolved by brackish water, unsaturated with respect to chloride (Yechieli et al., 2006; Legchenko et al., 2009; Ezersky $\&$ Frumkin, 2017). Instability of the salt cavity ceiling causes upward stoping through the mechanicallyweak sediments situated between the cavity and the surface (Fig. 7b). Ford \& Williams (2007, p. 385) report cases in different geological settings, where the stoping process propagated through $>1,000 \mathrm{~m}$ of cover rocks. This intermediate stage continues until the surface collapses and a sinkhole forms (Fig. 7c).
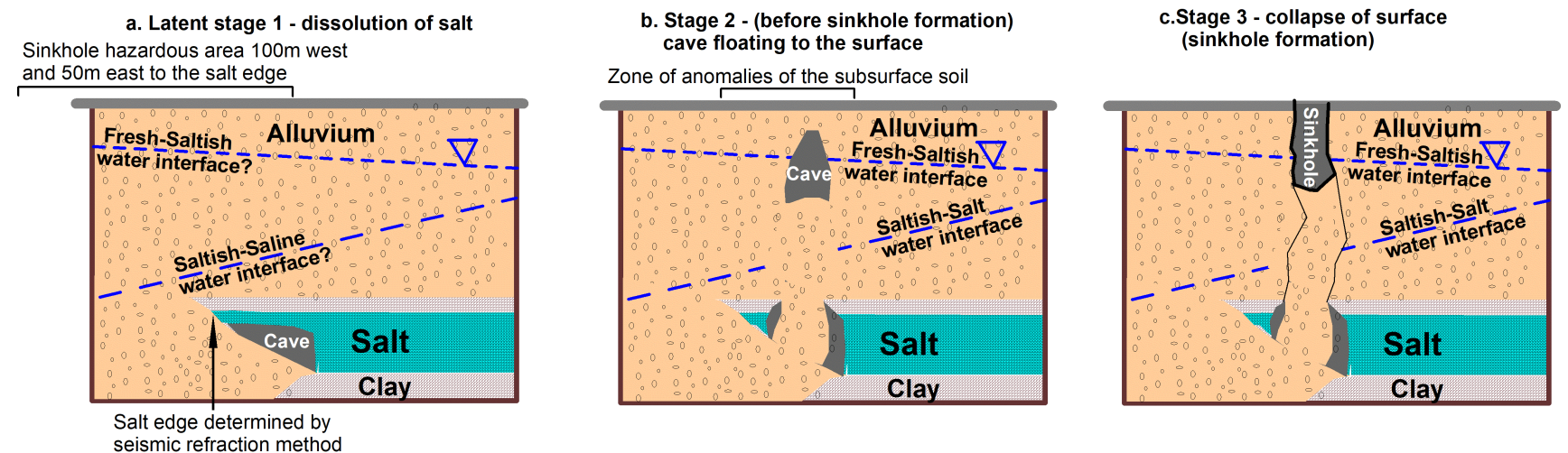

Fig. 7. Three stages of sinkhole formation at the salt edge: a generalized model. Note that although here is not salt west of the present salt edge, salt has been dissolved there earlier. Therefore, cavities may still propagate towards the surface. It is confirmed by statistics of sinkhole formation. a) Latent stage; b) upward propagation of cavity (stoping); c) sinkhole formation (permission of Elsevier, Frumkin et al., 2011).

Extrapolating the ongoing drop in the Dead Sea level, it can be predicted that the water table will fall progressively below the salt layer, leaving it within the vadose zone. This situation will favor karstification by downward vadose flow from ephemeral streams (e.g., Frumkin, 1994, Ezersky et al., 2011).

The aforementioned review presented above shows our knowledge of the DS sinkhole formation mechanism based on numerous geophysical studies carried out during last fourteen years.

On one hand, we have to check our prediction on spatial development of sinkholes in the Nahal Hever South site (Legchenko et al., 2008a) and change of the sinkhole formation mechanism caused by lowering of the groundwater table under salt layer top (Ezersky et al., 2011; Frumkin et al., 2011).

On the other hand, recent seismic reflection studies of Krawczyk et al. (2015) and Polom et al. (2016) did not reveal the salt layer in the Ghor Al-Haditha that permitted to propose a new mechanism of sinkhole formation in this area (Al-Halbouni et al., 2017). Thus, we should address both these issues, which we will discussed below.

\section{Exceptions to the general model / sinkhole sites not yet investigated}

Most of the sinkholes have been formed around the northern DS basin. These sinkholes range between depths of 5 to $50 \mathrm{~m}$ and lateral sizes of 3 to 100 $\mathrm{m}$, and they are constantly developing in the narrow (50-100 m width) strip along the coastal line (Fig. 1), slowly propagating from the south to the north.

The sinkholes recently developing in the southern area of the Israeli shore can be divided into two modes: (a) sinkholes I mode are similar to those of the northern basin although they are smaller in size; (b) sinkholes of II mode (small ones with diameter less than $1 \mathrm{~m}$ and depth of several dozens of centimeters) are formed on the DS dam surface (site 19 in Fig. 1), on the road pavement of route \#90 (Mt. Sedom area in Fig. 1).

With a lowering of the DS level various and complicated erosion patterns are developing in the Jordanian DS shores. Over time, channeling, gullying and head cut migration are occurring. Intensive incision of streams and gullies is propagating upstream towards the infrastructures, causing damages to the roads, bridges, earth dikes, and the hotels/recreation areas (Abou Karaki \& Closson, 2012). Two landslides and large sinkholes have appeared in 2004 in the Holiday Inn resort, and south of Marriott Hotel (Wadi Mukheira) (Sweimeh area, see site 23 in Fig. 1). Sinkholes also formed in the Wadi Mujib (site 22 in Fig. 1) and in the Arab Potash Company area.

Genesis of the northern sinkholes in Jordan and origin of sinkholes of mode II appeared on the Dam 5, highway \#90 in Israeli shores is still not well understood and should be investigated. The same holds for landslides developing along the northern Jordanian shore and Arab Potash Company

\section{METHODS}

\section{Geophysical methods to investigate the sinkhole problem}

Two aspects of the problem are considered: (1) investigation of the salt and (2) of the overlying sediments. Favorable ground conditions for applying geophysical techniques are available in the DS coastal area. For instance, seismic velocity of salt formation in the DS graben area is considerably higher than the surrounding rock environment. Such contrast in elastic velocities permits to map salt formations with a high reliability (Ezersky, 2006). Very low resistivity 
of the DS aquifers in the coastal area also creates a contrast with the surrounding sediments. It permits to locate the top of the DS brine as $1 \Omega m$ or $0.5 \Omega m$ interface with a high accuracy, minimal equivalency and to distinguish between salty and brackish water (Goldman et al., 1991; Kafri et al., 1997; Ezersky et al., 2011). Anomalous high resistivity of the sinkhole development sites was discovered in alluvial fans in Israel and Jordan (Ezersky, 2008, Al-Zoubi et al., 2007). It allows effectively mapping the sinkhole hazardous zones. Furthermore, it creates promising conditions for using the GPR technique for the detection of the signs of sinkhole hazard in the shallow (down to 10$15 \mathrm{~m}$ )-subsurface (Frumkin et al., 2009b, 2011). In the framework of sinkhole studies old geophysical methodologies were updated and new ones based on seismic and other surface methods were developed (Frumkin et al., 2011). Detailed considerations on these methods will be given in continuation.

\section{The Seismic Refraction Method (SRFR)}

The Seismic Refraction Method (SRFR) is a geophysical technique that is frequently used to determine the elastic characteristics of soils and rocks and their thicknesses. It is based on the measurement of the travel time of seismic waves refracted at the interfaces between subsurface layers of different velocity.

The General Reciprocal Method (GRM) permitted the determination of the detailed structure of the refractor and to give information about any localized lateral variations (Palmer, 1986). The method was applied to delineate the salt boundary with respect to the marine sediments (Legchenko et al., 2008c; Ezersky et al., 2010; Frumkin et al., 2011).

\section{Multichannel analysis of surface waves (MASW)}

Multichannel analysis of surface waves (MASW) (named also Surface wave prospecting (SWP)) is a standard approach to infer the 1-D $V_{s}$ structure for global earth seismology, near-surface geophysics, geotechnical, and civil engineering applications (Miller et al., 1999). Generally surface waves appear on multichannel seismic data and are regarded as a noise component, but here these waves are considered as a useful signal. Bodet et al. (2010) and Ezersky et al. (2013a) applied surface wave methods in the Ghor Al-Haditha site in Jordan and along the western DS shore in Israel. The Jordan study was focused on detection of underground voids using short seismic prospecting lines, with $4.5 \mathrm{~Hz}$ frequency geophones, whereas investigations on the western DS shore in Israel was aimed to evaluate spatial distribution of shear wave velocities throughout massive salt layers located at a depth of 30-50 m. These studies were carried out using $2.5 \mathrm{~Hz}$ vertical geophones able to reach $70 \mathrm{~m}$ depth from the surface.

\section{The Seismic Reflection Method (SRFL)}

The Seismic Reflection Method (SRFL) is based on reflection of elastic waves from interfaces between underground rock layers, determination of subsurface structure and its deformation. Use of the shallow seismic reflection method in detecting faults, cavities and intra-alluvial stratigraphy, in characterizing geologic, hydrologic, and stratigraphic conditions within $3 \mathrm{~m}$ to $30 \mathrm{~m}$ of the earth's surface is increasing (Steeples \& Miller, 1987). In the DS sinkhole phenomenon, the 2D SRFL method was applied in the Nahal Ze'elim, Mineral Beach sites. In the Mineral Beach, also the 3D SRFL method was applied to detect relationships between the faults and the sinkholes (Keydar et al., 2010, 2012, 2013; Ezersky \& Frumkin, 2013).

German researchers recently proposed a new methodology of S-wave reflection. S-waves have significantly lower velocities and can be used for more detailed investigation of the shallow subsurface (Krawczyk et al., 2012; Polom et al., 2013). This new methodology was used in the Ghor Al-Haditha area to investigate the presence or not of a salt layer.

\section{The Magnetic Resonance Sounding method (MRS)}

The Magnetic Resonance Sounding method (MRS), also known as Surface Nuclear Magnetic Resonance (SNMR), was specifically developed for groundwater investigations (Legchenko \& Valla, 2002). This method is selectively sensitive to water in the subsurface and allows carrying out a non-invasive estimation of the hydrodynamic properties (Legchenko et al., 2004; 2006a). The field set-up consists of a wire loop set on the surface. The investigation depth depends on the loop size and may vary from 20 to $150 \mathrm{~m}$. For the MRS measurements, the loop is energized by a pulse of alternating current. The magnetic-resonance signal can be measured with one or more surface loops after the excitation current is cut off (Hertrich, 2008; Hertrich et al., 2009). One sounding consists of measuring the MRS signal for different values of the current in the loop. Two main parameters are derived from the MRS measurements (Lachassagne et al., 2005): (a) the MRS water content (w), which is closely related to the amplitude of the MRS signal; and (b) the MRS relaxation time $T_{1}$. Assuming a horizontal stratification, inversion of sounding data estimates the water content $w(z)$ and the relaxation time $T_{1}(z)$ as a function of depth $(z)$ (Legchenko \& Shushakov, 1998; Müller-Petke et al., 2013). Combination of the MRS water content and relaxation time helps estimating rock hydraulic conductivity as $K_{M R S}=C_{p} w T_{1}^{2}$, with $C_{p}$ being an empirical constant that can be calibrated to similar hydrogeological parameters using a pumping test.

MRS is an efficient tool not only for characterizing aquifers but also for locating water-filled voids in the subsurface (Vouillamoz et al., 2003; Boucher et al., 2006). Legchenko et al. (2006a), have shown using both numerical modeling and field measurements, that the MRS can be applied to investigate the weathered part of hard-rock aquifers, when the product of the free water content multiplied by aquifer thickness is $>0.2$. This is the case in the northern DS coastal areas, where 10-30 m-thick salt layers comprise more than $3.8 \%$ porosity with a water content of $\geq 2.3 \%$ (Ezersky \& Goretsky, 2014). The MRS data can also been used for constraining hydrogeological modeling (Boucher et al., 2012). 
Usually MRS is used in a 1D or 2D mode (Legchenko \& Valla, 2002; Girard et al., 2007; Hertrich et al., 2007). However, the lateral resolution of the method may be insufficient for identifying relatively small water-saturated formations for targeting a drilling program. For this study a newly developed 3D implementation of the Magnetic Resonance Tomography (MRT) or 3D-SNMR method was used in framework of the Dead Sea sinkhole problem (Legchenko et al., 2011). For instance, it was established that in high conductive environment (like the Dead Sea groundwater), the 3D-SNMR measurements should be accompanied by TEM measurements for every loop. Depth of investigation by these methods in the DS area is of about $40-50 \mathrm{~m}$ (Legchenko et al., 2008a). The 3D-SNMR method was used to determine standard parameters of the aquifers (relaxation time $T_{1}$, water content $\mathrm{W}$, hydraulic conductivity $\mathrm{K}$, etc.), evaluation of karstic cavity volume (Legchenko et al., 2008b), and lithology identification (Legchenko et al., 2009).

\section{The Time Electromagnetic (TEM)}

The Time Electromagnetic (TEM) method (named also, Time Domain Electromagnetic - TDEM method) is sensitive to subsurface conductivity, which is closely linked to groundwater salinity. This method is routinely used for vertical depth soundings for monitoring groundwater salinity and locating the fresh-saline water interface in coastal areas (Goldman et al., 1991; Barsukov et al., 2015). However, TDEM is sensitive to both the salinity of groundwater and the porosity of rocks. Kafri et al. (1997) have shown that a bulk resistivity of $1 \Omega m$ or less is typical of the concentrated brine in the Dead Sea region, reflecting a lithology that contains the DS brine or slightly diluted brine. Therefore, the $1 \Omega m$ interface surface is an important index of the structure and geometry of the fresh (brackish)/saline water (brine) interface. In the DS problem, the TEM method was also used as: (a) a quasi 3D technique based on numerous $1 \mathrm{D}$ soundings to map variations in resistivity throughout the area (Ezersky et al., 2011); (b) to determine salt layer geometry and properties (Frumkin et al., 2011, Ezersky \& Legchenko, 2014, 2015); and (c) to map salinity and aggressiveness of DS aquifers (Ezersky \& Frumkin, 2017).

\section{Microgravity technique}

Microgravity technique is based on the principle to locate areas of contrasting density in the subsurface by collecting surface gravity measurements, their processing and qualitative and quantitative analysis (including 3D gravity field modeling). In the DS sinkhole problem, the method was tested to detect underground voids and thus to predict sinkhole formation (El-Isa et al., 1995; Rybakov et al., 2001). One of the problems resolved in the framework of this investigation is an improvement of the microgravity method based on suppression of the ambient noises (Eppelbaum \& Khesin, 2004; Eppelbaum, 2007). Besides complex subsurface geology, microgravity method application essentially disturbs a giant gravity field horizontal gradient caused by many kilometers of loose deposits and salt accomplished within the Dead Sea Transform (Garfunkel, 1997). The problem is resolved by 3-D microgravity modeling aimed to estimate qualitative and quantitative parameters of buried karst cavities, detect the buried salt dissolution caverns and verify our calculations with in-situ geodetic measurements. This method was tested in the Nahal Hever South area (Eppelbaum et al., 2008), Ein Gedi-Arugot area (Ezersky et al., 2013b) and Ghor Al-Haditha area (Al-Zoubi et al., 2013) (see Fig. 1 for site location).

\section{Micromagnetic study}

Micromagnetic study was carried out to test the possibility of detecting weak magnetic anomalies connected with buried void detection in the subsurface (Rybakov et al., 2005). The principal possibilities of the micromagnetic method application in complex Israeli physical-environmental conditions are presented in detail in Eppelbaum et al. (2001) and Eppelbaum (2015a, b).

\section{Combined studies}

Combination TEM and 3D-SNMR. Legchenko et al. (2009) have shown that both SNMR and TEM enable us to resolve the fundamental uncertainty in TEM interpretation caused by the equivalence between the groundwater resistivity and lithology. It is because the 3D-SNMR signal depends on size of particles characterizing different lithology (Stephens et al., 1998), whereas TDEM is sensitive to both the salinity of groundwater and the porosity of rocks. Thus, the combined use of 3D-SNMR and TEM allows us to perform advanced data interpretation when investigating heterogeneous water-saturated formations.

Combination SRFR and MASW. Two methods allow estimation of $V_{p}$ and $V_{s}$ velocities responsible for dynamic elastic parameters like Young's modulus $\left(E_{d}\right)$, Shear modulus $\left(G_{d}\right)$ and Poisson's Ratio $\left(v_{d}\right)$. Shear wave velocity $\left(V_{s}\right)$ profile is usually obtained from the S-wave seismic refraction surveys (Palmer, 1986). However, use of the latter is often hampered by problems in generating $\mathrm{S}$-waves due to the weak source and the difficulties in performing geophysical survey in urban areas. Another method allowing constructing the subsurface $V_{s}$ profile is the widely used Multichannel Analysis of Surface Waves (MASW). It is especially important for studying of the salt layers located at a depth of about 30-70 m.

Combination MASW and 3D-SNMR. Ezersky \& Legchenko (2014) have suggested a methodology of evaluation in-situ salt karstification based on correlative interrelations between the hydraulic conductivity $(\mathrm{K})$ (determined by 3D-SNMR) and the shear wave velocity $V_{s}$ (derived from MASW along the same lines) in areas of the DS sinkhole development. A quantitative estimate of such in-situ salt karstification would be an important indicator of sinkhole hazard. One of the indications of salt karstification is its increased hydraulic conductivity, caused by the development of dissolution cavities forming conducting channels within the salt layer. Understanding of the field 
relationships was justified by similar interrelations obtained in the laboratory analyses of the DS salt samples (Ezersky \& Goretsky, 2014).

\section{RESULTS}

Results of geophysical researches carried out in the sinkhole development sites are briefly presented in Table 4.

\section{Results of study in the western and eastern DS sites}

In order to check the validity of the salt edge dissolution model in other areas of the Dead Sea we have reinterpreted previous seismic refraction data obtained by the Geophysical Institute of Israel during 1999-2004 and performed new seismic refraction surveys. Ten sinkhole sites in Israel and one in Jordan have been investigated using the seismic refraction method (Ezersky \& Legchenko, 2008). Results of salt mapping in the Nahal Ze'elim area were published by Ezersky \& Legchenko (2015). All maps are based on the salt velocity criterion $V_{p}>2,900 \mathrm{~m} / \mathrm{s}$. The map presented in Fig. 8 shows the sinkhole sites studied using the seismic refraction method, the locations of boreholes drilled by the Geological Survey of Israel (GSI), and that of the seismic lines. It was established that sinkholes are conform to the buried salt layer edge
(Ezersky, 2006). The most detailed maps of the salt edge have been presented in Fig. 9. Sites are distributed along the western DS shores in Israel (Fig. 9 a-d) and on the eastern shore in Jordan (Fig. 10b-e).

The Ein Gedi area is situated in the central part of the western Dead Sea shoreline on the Nahal Arugot alluvial fan about $\sim 37 \mathrm{~m}$ above the DS level in 2017 (see Fig. 8 for location). The sinkholes at the Ein Gedi district formed in areas affected by human activity. The first sinkholes appeared in 1995 and from 1995 to 2015 more than 250 sinkholes have opened up at the Ein Gedi Caravan Park, the Palm-Tree Plantation and in the Nahal Arugot area. The sinkhole layouts are shown in Fig. 9a. Sinkholes are arranged along a tortuous line within a narrow, 50-70 m wide zone, about 1,750 $\mathrm{m}$ long trending south-southeast. The sinkhole strip crosses route \#90, with sinkholes occurring on both sides of the highway, although, so far no sinkholes have developed immediately under it. The sinkholes are continuing to develop today.

The Mineral Beach area, covering $\sim 1 \mathrm{~km}^{2}$, is located at the western coast of the central part of the northern DS basin (Fig. 8 for site location and Fig. 9b). The study site is located between the Dead Sea shoreline and Route \#90 (the main road along the western DS shore). The area comprises the Mineral Spa, where natural black mud and sulfur-rich hydrothermal water with a temperature of $39^{\circ} \mathrm{C}$, attracts tourists from Israel

Table 4. Results of geophysical studies in the DS sinkhole problem.

\begin{tabular}{|c|c|c|}
\hline Method & Main results & References \\
\hline SRFR & $\begin{array}{c}\text { 1. Sinkhole are formed along salt edge (dissolution front) } \\
\text { 2.Criterion of salt was substantiated } \\
\text { 3. The in-situ P-wave velocity }\left(V_{p}\right) \text { varies between } 2,900 \mathrm{~m} / \mathrm{s} \text { (rarely, } \\
2,850 \mathrm{~m} / \mathrm{s} \text { ) to } 4,250 \mathrm{~m} / \mathrm{s} \text {. The zone of compressional velocity } \\
V_{p_{\min }}=2,900 \mathrm{~m} / \mathrm{s} \text { is lower limit of salt layer. Salt edge was delineated along } \\
\text { western DS shore and in Ghor Al-Haditha in Jordan. }\end{array}$ & $\begin{array}{l}\text { Ezersky (2006); } \\
\text { Ezersky et al., 2010; }\end{array}$ \\
\hline MASW & $\begin{array}{l}\text { Search of underground voids in soil; Measurements of shear wave velocities } \\
\left(V_{s}\right) \text { in-situ salt layers; In-situ salt } V_{s} \text { is varied between } 750-800 \mathrm{~m} / \mathrm{s} \text { and } \\
1,800 \mathrm{~m} / \mathrm{s} \text {. Salt classification based on } V_{s} \text { was suggested }\end{array}$ & $\begin{array}{l}\text { Bodet et al., 2010, Ezersky } \\
\text { et al., 2013a; Ezersky \& } \\
\text { Goretsky, } 2014\end{array}$ \\
\hline SRFL & $\begin{array}{l}\text { 2-D, 3-D study of faults-sinkholes and salt-faults relations in } \\
\text { the DS sinkhole areas }\end{array}$ & $\begin{array}{l}\text { Keydar et al., 2012; 2013, } \\
\text { Ezersky \& Frumkin, } 2013\end{array}$ \\
\hline $\begin{array}{l}\text { Transient } \\
\text { Electromagnetic } \\
\text { (TEM, TDEM) }\end{array}$ & $\begin{array}{l}\text { Localization of brackish-salt water interface. Evaluation of DS water salinity } \\
\text { based on bulk resistivity, mapping of sinkhole development sites; estimation } \\
\text { of salt layer thickness }\end{array}$ & $\begin{array}{l}\text { Ezersky et al., 2011; Frumkin } \\
\text { et al., 2011; Ezersky \& } \\
\text { Legchenko, 2015; Ezersky \& } \\
\text { Frumkin, 2017. }\end{array}$ \\
\hline $\begin{array}{l}\text { Electric Resistivity } \\
\text { Tomography (ERT) }\end{array}$ & $\begin{array}{l}\text { Detection of sinkhole sites based on high resistivity; study of resistivity } \\
\text { structure of subsurface, }\end{array}$ & $\begin{array}{l}\text { Al-Zoubi et al., 2007; Ezersky, } \\
\text { 2008; Frumkin et al., } 2011\end{array}$ \\
\hline $\begin{array}{l}\text { Magnetic Resonance } \\
\text { Sounding (MRS) } \\
\text { or Surface Nuclear } \\
\text { Magnetic Resonance } \\
\text { (SNMR) + 3D-SNMR }\end{array}$ & $\begin{array}{l}\text { Determination of water content (Wi), relaxation time }\left(T_{1}\right) \text { and hydraulic } \\
\text { conductivity }(\mathrm{K}) \text { of the subsurface, evaluation of water saturated caves } \\
\text { volume. In practice, a karst aquifer generally is composed of karst channels } \\
\text { and caverns. In the DS conditions a long apparent-relaxation time } T_{1} \text { ap } \\
>450 \mathrm{~ms} \text { are an unambiguous signature of karst. The signal generated by } \\
\text { water in a porous medium is characterized by a shorter relaxation time } \\
\qquad T_{1}<400 \mathrm{~ms} \text {. }\end{array}$ & $\begin{array}{l}\text { Legchenko et al., 2004, } \\
\text { Legchenko et al.,2006a, b; } \\
\text { 2008a, b; 2011; Ezersky et al., } \\
2010\end{array}$ \\
\hline MRS + TEM & $\begin{array}{c}\text { Investigation of subsurface lithology: sandy gravel and silty } \\
\text { sediments were identified }\end{array}$ & Legchenko et al., 2009 \\
\hline MRS+MASW & $\begin{array}{c}\text { Evaluation of the soil hydraulic conductivity }(\mathrm{K}) \text { based on correlation } \\
\text { between } V_{s} \text { and } \mathrm{K} \text {. hydraulic conductivity }(\mathrm{K}) \text { in the same zones varies } \\
\text { between about } 10^{-4} \mathrm{~m} / \mathrm{s} \text { to slightly over } 10^{-8} \mathrm{~m} / \mathrm{s} \text {. Sinkholes form within } \\
\text { highly conductive zones with } \mathrm{K} \geq 2^{*} 10^{-5}\end{array}$ & Ezersky \& Legchenko, 2014 \\
\hline $\begin{array}{l}\text { Ground penetrating } \\
\text { radar (GPR) }\end{array}$ & $\begin{array}{c}\text { Investigation of shallow structure of sinkhole sites, } \\
\text { detection of faults and caverns }\end{array}$ & Frumkin et al., 2011; \\
\hline Microgravity & Detection of caverns and evaluation of their volume & $\begin{array}{l}\text { El-Isa et al., 1995; Rybakov et } \\
\text { al., 2001; Eppelbaum et al., } \\
\text { 2008; Al-Zoubi et al., 2013; } \\
\text { Ezersky et al., 2013b, }\end{array}$ \\
\hline Micromagnetic & Detection of underground cavities & Rybakov et al., 2005 \\
\hline
\end{tabular}




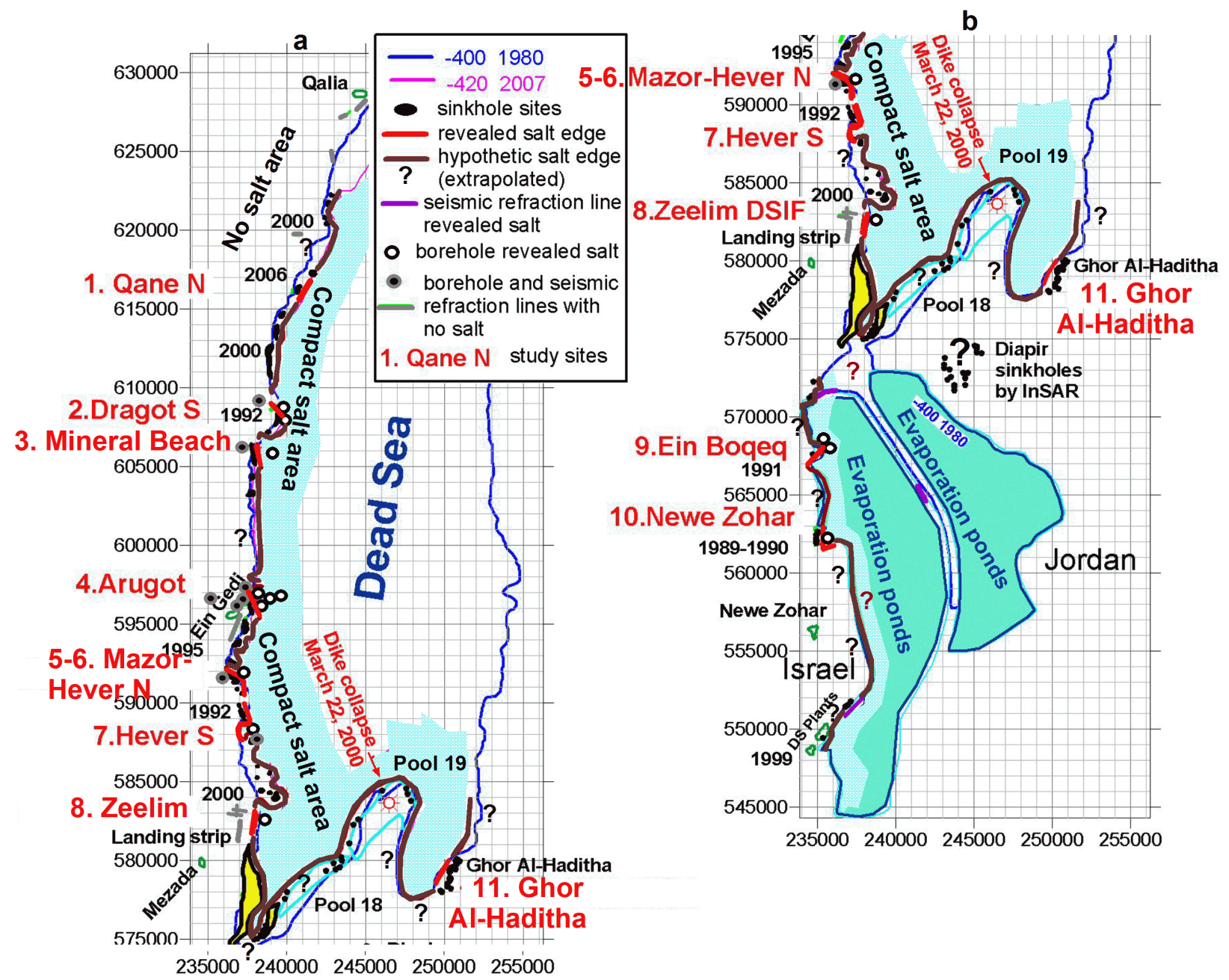

Fig. 8. Sinkhole sites (numbered red names) studied using seismic refraction method.

and abroad. Around Mineral Spa, sinkholes develop in both mudflat (south) and alluvial fan (north) areas. Fig. 9b illustrates that sinkhole development is mainly linear, along a salt layer edge or controlled by a fault (Frumkin et al., 2011). A salt layer with a cavity was intersected by MN-2 borehole, which crossed DS mud from the surface to $18 \mathrm{~m}$ deep. Borehole MN-1 crossed a sandy-gravel section and did not discover a salt layer. Soon after drilling, the borehole MN-2 collapsed into a newly developed sinkhole, which was then east of the salt layer front. Ezersky (2011) has delineated the salt layer edge in the Mineral Beach study site (lilac solid line in Fig. 9b). The specified salt border is shown in Fig. 9b.

Frumkin et al. (2011) have shown that the western border of the salt at the north of the area is located in alluvium composed of sandy-gravel sediments.

The Newe Zohar (NZ) site map is shown in Fig. 9c (see Fig. 8b for location). The NZ site is a settlement with several thousands of residents and includes evaporation ponds (EPs) fed by water pumped from the northern DS basin (Ezersky et al., 2010). Borehole $\mathrm{NZ}-1$ penetrated a $27 \mathrm{~m}$ thick salt layer whose top is situated at a depth of $50 \mathrm{~m}$. NZ is the first area of the western DS coast where sinkholes affected the main road in 1989. The map of a $1,000 \times 600 \mathrm{~m}$ area using the seismic refraction method was generated to delineate the edge of the salt layer (Fig. 9c). The thick lilac line in Fig. 9c represents the western edge of the compact salt. The distribution of sinkholes shows a good spatial correlation with the mapped salt edge. Recent sinkholes (white circles) have developed along the salt border. In accordance to this map, the Tamar Regional Council carried out during 2008-2012 excavations along the DS water line bordering the salt edge. No new sinkholes have appeared since. Thus, in the NZ site the distribution of sinkholes supports the salt edge dissolution model.

The Ein Boqeq area of $1.5-2.0 \mathrm{~km}$ long and 250$300 \mathrm{~m}$ width extends along the southern DS basin (recently evaporation ponds artificially filled by pumping DS water from the northern basin (see Fig. $8 \mathrm{~b}$ for location). Numerous hotels are located through Ein Boqeq that is also named the Hotel area. The salt layer edge extends in the N-S direction (Fig. 9d). The geological profile is composed of pebbles, cobbles and clayey-sandy sediments. The geological description of the Ein Boqeq site is presented by boreholes EB-1 and EB-2 (Yechieli et al., 2004). Borehole EB-3E (Fig. 6b) was drilled later to collect salt samples. The boreholes crossed sandy-gravel alluvium overlying the $28 \mathrm{~m}$ thick salt unit located at $26 \mathrm{~m}$ depth. Embryos of 6 small shallow sinkholes were detected during drilling of the EB-1 borehole. No other sinkholes were detected. Differently from other sites at Ein Boqeq the groundwater is located some 3-4 m from surface, much higher than elsewhere.

The Ghor Al-Haditha area is located south-east of the northern Dead Sea basin (site 11 in Fig. 8). Lithological structure of the eastern DS side, as 
the western one, is composed of sediments of Early Holocene overlain in places by alluvium and soil (Fig. 10a) (Bartov et al., 2006) at approximately the same elevations. Alluvial fan deposits of the Wadi Ibn Hamad cover the southern part of this area.

The sinkholes at the eastern coast of the Dead Sea started forming in the 1980s (Taqieddin et al., 2000). The area of the sinkhole formation is a gently inclined wave eroded platform, about $3 \mathrm{~km}$ wide and located east of the Lisan Peninsula. This area formed the bed of the Dead Sea during a period of higher DS level (390 m b.m.s.1.).

Considering the generalized geological profile in Fig. 5 one can see that lithological structure from both sides of the geological section through the DS (considering only Ghor Al-Haditha area) must be similar. This is confirmed by two boreholes, which were drilled by El-Isa (1995) at the central part of the Ghor Al-Haditha area (Fig. 10b) down to 49-51 m. In accordance with the borehole data (El-Isa et al., 1995, p. 27 Fig. 2-9) the upper section of the Ghor Al-Haditha is composed of sandy-gravel sediments similar to these located on alluvial fans on the western side (HS-2 or EB-3E in Figs. 6b, d, respectively). Bottom lithology of the western borehole 2 (50-51 m deep) - and eastern borehole $1(45-46 \mathrm{~m})$ is presented by silt and marl. Both boreholes do not contain any evidences of thick mud layers lower than the borehole bottom. The salt layer was not discovered also in boreholes because both of t,hem were drilled with fresh water and cannot reveal salt as a whole. However, similarity of lithological structure in both DS sides as well as in the upper parts of the boreholes, enable us to suggest that salt layer would be formed in the eastern part similarly to the western side. Moreover, Taqieddin et al. (2000) have presumed that the salt layer occurs at the depth of 25-50 $\mathrm{m}$ and may also occur at 10-15 $\mathrm{m}$ depth.

Frumkin et al. (2011), to verify a presence of the salt layer in the Ghor Al-Haditha, analyzed seismic refraction data acquired by El-Isa et al. (1995). This analysis has shown that there are two zones with the different velocities $V_{p}$ along the refractor. The western part of the area is composed of a high velocity layer with $V_{p}>2,900 \mathrm{~m} / \mathrm{s}$, whereas the eastern part of the area is composed of a low velocity layer

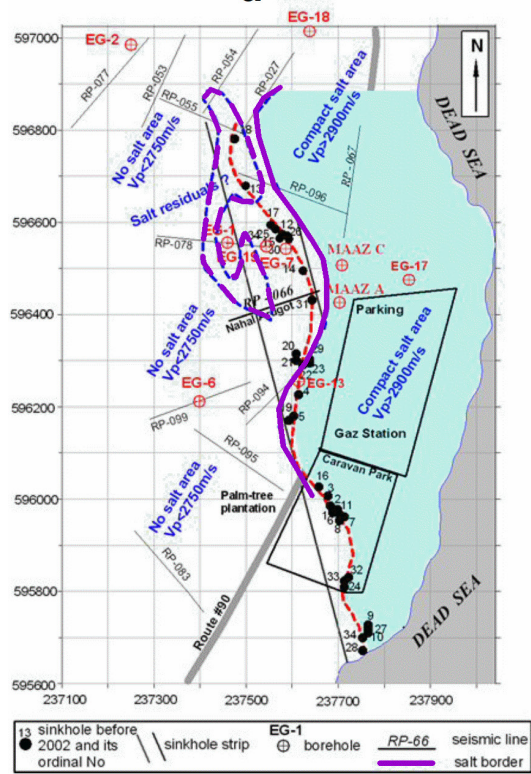

b

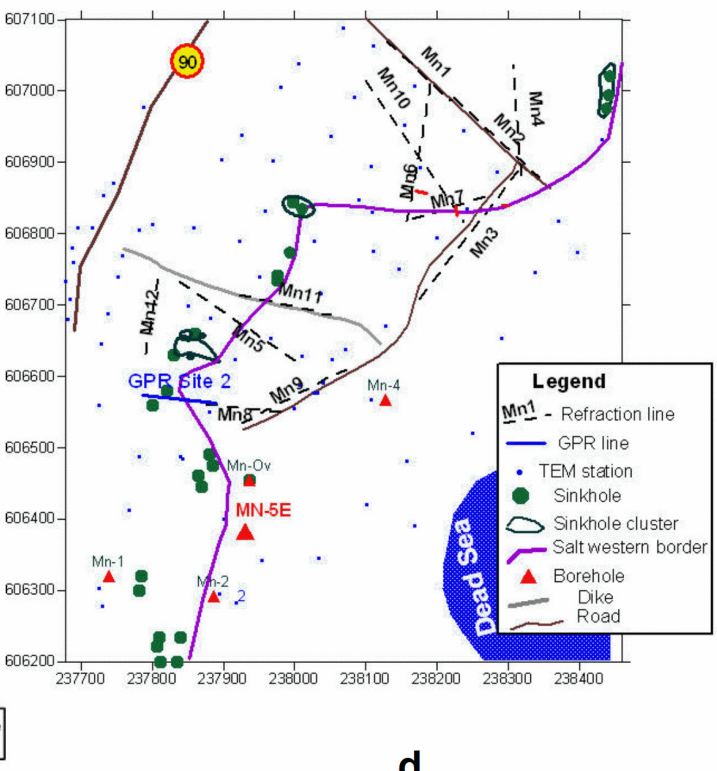

d
C

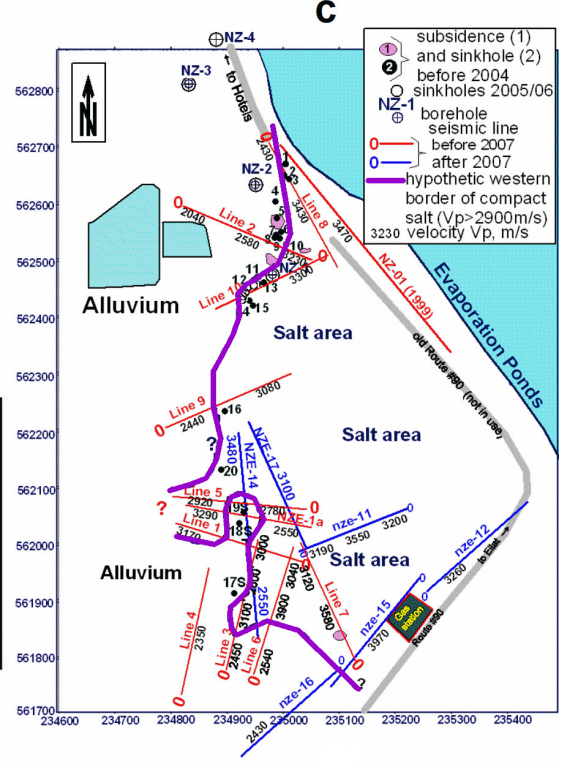

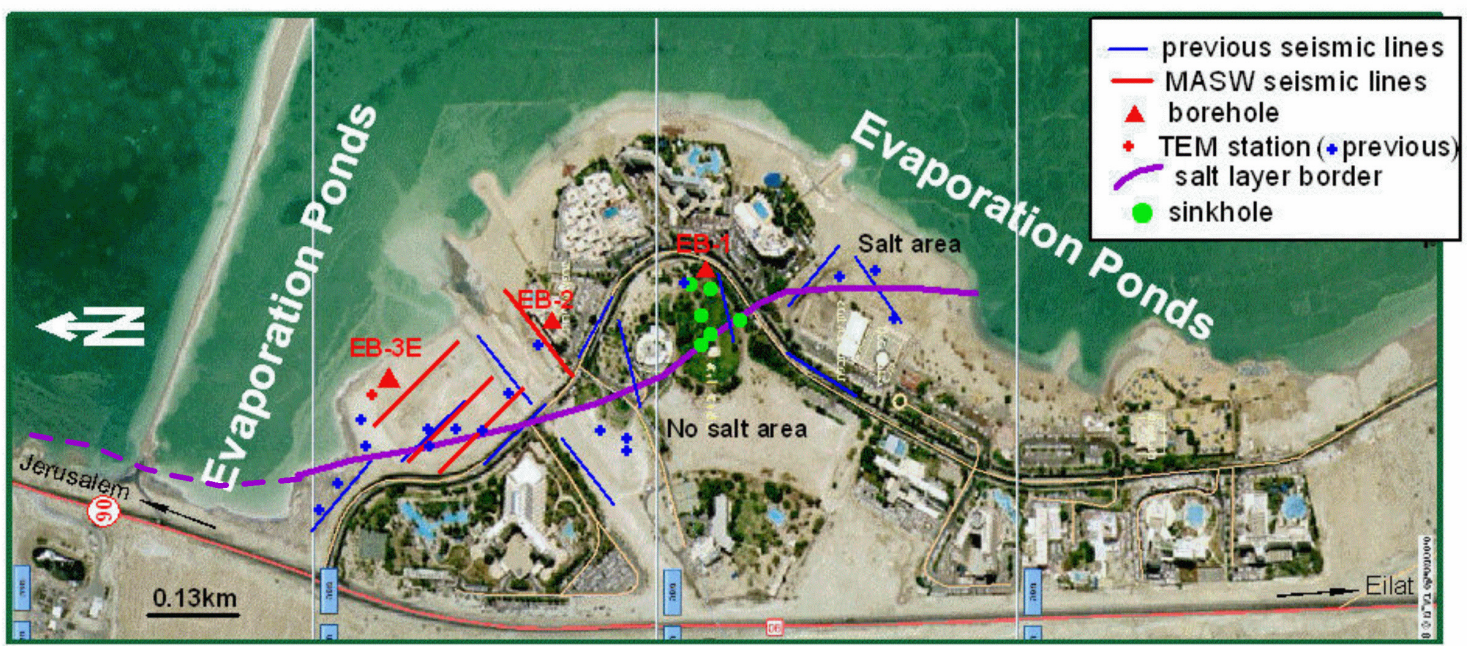

Fig. 9. Salt location maps based on seismic refraction surveys in number of western DS sites; a) Ein Gedi - Nahal Arugot area (line length is of $2 \mathrm{~km}$ ); b) Mineral Beach; c) Newe Zohar; d) North of Ein Boqeq (DS Hotels area). Salt edge is denoted by thick lilac line. Sinkholes are arranged (with some small deflections) along this line. a-d) salt border is located west to DS, [a) Ezersky, 2006; b) Frumkin et al., 2011; c) Ezersky et al., 2010; d) Ezersky 2011, unpublished report]. 
a. Ghor Al-Haditha geological section based on Taquedine et al., 2000; and seismic data

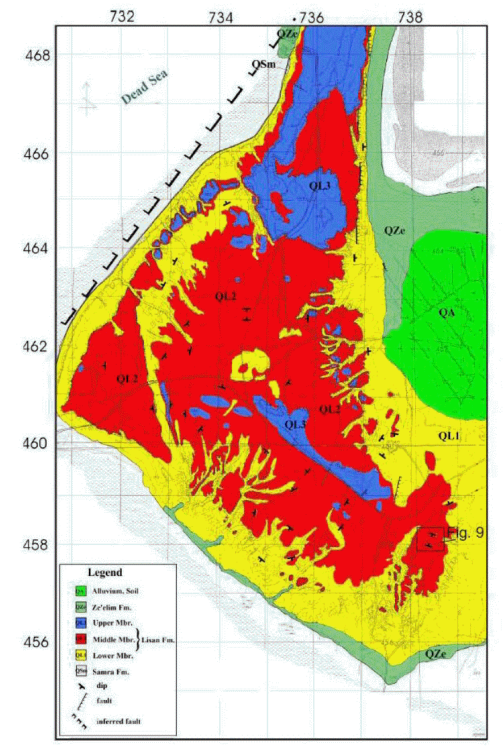

\section{b. Location map at the Ghor Al-Haditha}

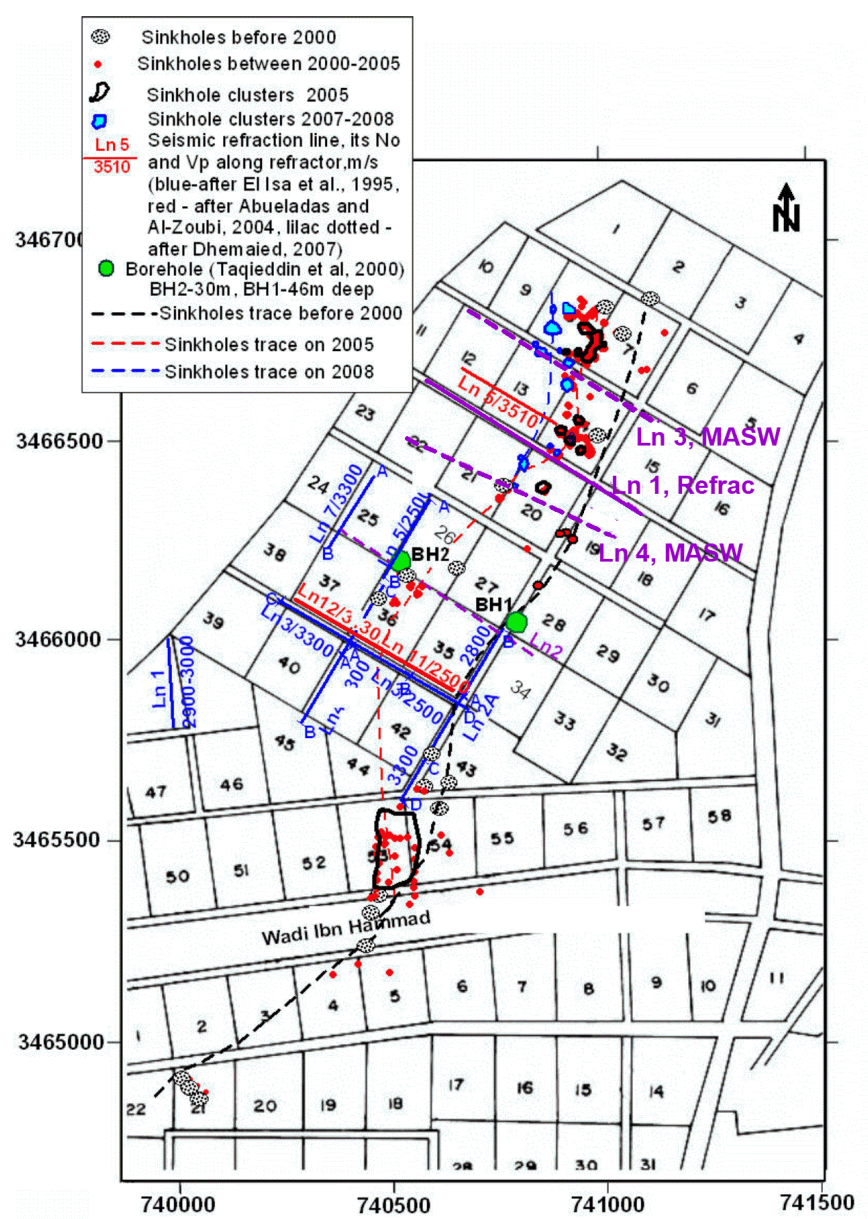

c. Velocity depth section along Lines 11-12, (Al-Zoubi et al., 2004)

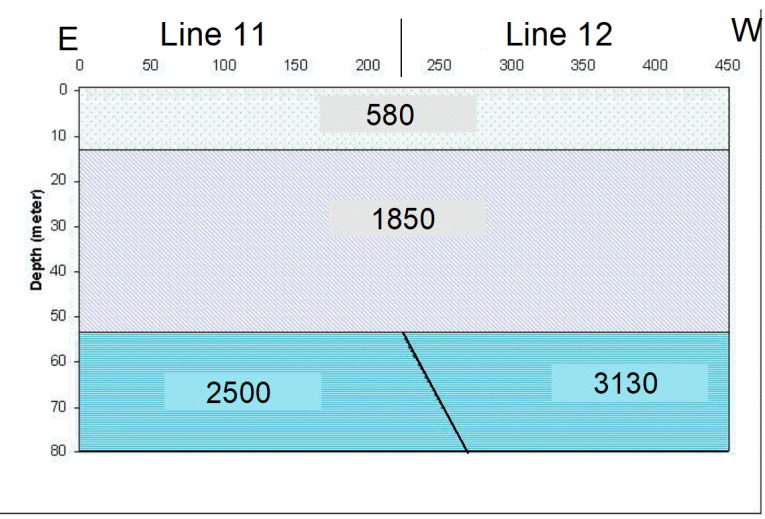

d. Tomography velocity depth section along Line 1 (Dhemaied, 2007)

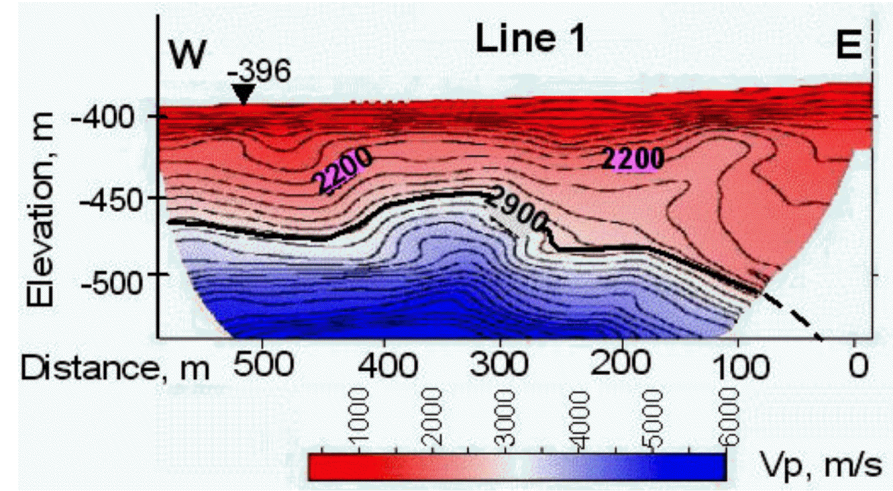

\section{e. Vs depth sections along Line 3 (upper) and Line 4 (lower). After Bodet et al., 2010}
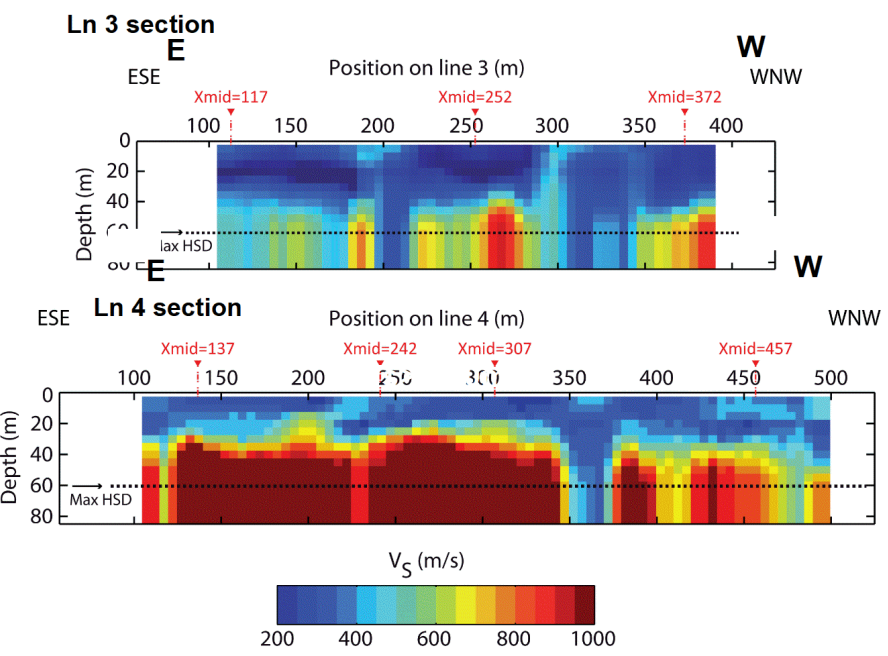

Fig. 10. Seismic studies carried out in the Ghor Al-Haditha area. a) geological map; b) location map with carried out seismic studies; c) Seismic refraction section performed by Abueladas and Al-Zoubi (2004); d) One of four refraction tomography section carried out by Dhemaied (2007); e) Two MASW sections performed in 2007 (Bodet et. Al, 2010). Note that all seismic sections show high velocity $(>2,900 \mathrm{~m} / \mathrm{s}$ ) layer located at a depth of 40-50 m, which in conditions of Dead Sea can be salt only (Ezersky, 2006). The results acquired by El-Isa et al. (1995) supporting these finding were presented by Ezersky et al. (2013b). [a) Permission of IJES, Bartov et al. 2006; c-e) Permissions of all authors, with reference to Camerlynck et al., 2012)]. 
with refractor velocity $V_{p}<2,500 \mathrm{~m} / \mathrm{s}$. A depth from surface to refractor was estimated as $40-50 \mathrm{~m}$. The border between the high and low velocity layers was interpreted as the salt edge. The velocities from rocks with velocity more than $2,900 \mathrm{~m} / \mathrm{s}$ were interpreted as salt layer. These data were represented also in Ezersky et al. (2013b). In continuation, we have to present data acquired later by other researchers (Fig. 10c-e). Location of seismic lines is presented in Fig. 10b.

Three seismic refraction sections were acquired in 2003 by Abueladas \& Al-Zoubi (2004). Location of these sections is shown in Fig. 10b (red lines) and one of the refraction sections is presented in Fig. 10c. Section along the western Line 12 shows refractor velocity $V_{p}=3,300 \mathrm{~m} / \mathrm{s}$ (possibly salt) and eastern Line 11 shows refractor velocity $V_{p}=2,500 \mathrm{~m} / \mathrm{s}$ (obviously not salt). Velocity $V_{p}$ along the refractor of Line 5 was $3,510 \mathrm{~m} / \mathrm{s}$. The entire line is located to the west of sinkholes.

Seismic refraction tomography studies along four of the same lines were carried out by Dhemaied (2007). Location of one of 4 Lines (orange) is shown in Fig. $10 \mathrm{~b}$ and the $V_{p}$ velocity section is presented in Fig $10 \mathrm{~d}$. There is a refractor velocity of $2,900 \mathrm{~m} / \mathrm{s}$ in the lower part of the section at a depth of 40-50 m. All $V_{p}$ sections have shown a similar structure.

Surface wave prospecting was carried out in 2007 along two (lila thick dashed) lines 3 and 4 in Fig. 10b using the Multichannel Analysis of Surface Waves (MASW) method (Bodet et al., 2010; Ezersky et al., 2013a). Two $V_{s}$ depth sections are shown in Fig. 10e. One can see that the lower part of the section at $40 \mathrm{~m}$, approximately, is composed of high $V_{s}$ velocity unit $\left(V_{s}>1,000 \mathrm{~m} / \mathrm{s}\right)$ interpreted as salt. Penetration depth is evaluated as $60 \mathrm{~m}$ (dotted line). Bodet et al. (2010) note that Line 3, crossing the sinkhole development sites, is characterized by degraded salt layer, whereas line 4 shows a relatively homogeneous reflector (Ezersky et al., 2013a).

\section{Results of study in the Nahal Hever South area}

An example of study in the Nahal Hever South (NHS) area and prediction of future sinkhole development using geophysical methodologies is considered in this chapter.

The studied Nahal Hever South (NHS) area is located in the central part of the northern Dead Sea Basin in Israel (Fig. 8a). Three boreholes (HS-1, HS-2, and HS-3) were drilled in the area (Yechieli et al., 2004; Ezersky et al., 2009). The lithological profile of boreholes HS-2 and HS-3 is shown in Figs. 6c and $6 \mathrm{~d}$. The geological section is composed of alluvial fan sediments up to a depth of $18 \mathrm{~m}$, a 5-m-thick marl layer, and an 11-m-thick salt layer. A clay and gravel formation underlies the salt layer. The visible section of the sinkholes consists of sand-gravel intercalating marl layers.

The borehole HS-2 drilled in this zone (Fig. 6d) penetrated the 11-m thick salt layer at a depth of $24 \mathrm{~m}$. The longitudinal velocity $\left(V_{p}\right)$ map (generated in 2007) is presented in Fig. 11a. The blue area of high velocity $\left(V_{p}=2,940-3,600 \mathrm{~m} / \mathrm{s}\right)$ is, therefore, identified within the salt unit (Ezersky, 2006). The origin of the low velocity zone $\left(V_{p}=2,200-2,770 \mathrm{~m} / \mathrm{s}\right)$ is also clear from the drilling data. Examples of sinkhole images are shown in Figs 11b-e.

Borehole HS-3 (located precisely on the southern edge of the low velocity area) revealed a mud-filled cavity at a depth interval of $23-28 \mathrm{~m}$, which is interpreted as a dissolved salt zone (Fig. 6c).

Each 3D-SNMR image is composed of individual SNMR measurements. A total of 24 SNMR soundings have been performed in 2007. Each SNMR sounding was accompanied by a TEM sounding. SNMR measurements were carried out with a square loop of $100 \times 100 \mathrm{~m}$.

For TEM measurements a coincident $25 \times 25 \mathrm{~m}$ loop was used. All SNMR measurements were carried out using the NUMIS ${ }^{\text {Plus }}$ SNMR (MRS) system developed by IRIS Instruments (France). Previous investigations (Legchenko et al., 2008a) have shown that in the Nahal Hever area, where the subsurface is characterized by very high electrical conductivity, the depth of investigation with this loop was estimated as $45-50 \mathrm{~m}$. The location of SNMR stations is shown in Fig. 12 .

The relaxation time $\left(T_{1}\right)$ map (Fig. 13a) shows that the average $T_{1}$ varies between approximately 50 and $400 \mathrm{~ms}$. Larger values of $T_{1}$ correspond to a sand formation. The map of the water content (Fig. 13b) and 3D image of the water content distribution derived from SNMR results (Fig. 13c) allow locating the aquifer.

TEM investigations carried out in the NHS have shown that bulk resistivity in the DS southern area is very low and varies in the range of 0.2-0.4 $\Omega \mathrm{m}$ increasing in the northern direction, where it reaches resistivity of 0.45-0.7 $\Omega m$ (Ezersky et al., 2011). Resistivity less than $0.4 \Omega \mathrm{m}$ indicates lime carbonate (LC) material saturated with DS brine. The resistivity ranged between 0.45 and $0.7 \Omega m$ characterizes sandygravel material also saturated with DS brine. In sandy material, the 1 interface shows the DS brine level. Such an increase in the bulk resistivity is connected in the NHS with a change in lithology, but not in water salinity (Legchenko et al., 2009).

3D-SNMR results suggested that the immediate risk of the development of new sinkholes is presently lower in the southern part of the area than in the northern part (Legchenko et al., 2006b, 2008b). Moreover, future sinkholes in the area after 2005 will likely develop in the northern direction.

Let us consider temporal sinkhole development throughout the NHS area (Fig. 14). Maps of sinkhole distribution are based on the DS sinkhole database 1998-2016. In spite of very simple statistical analysis based on number of sinkholes, but not their surface area, some main spatial regularities of sinkhole development can be seen on the presented maps.

One can see in Fig. 14a that up to 2004, 16 sinkholes are grouped in the southern part of the NHS area. This area is characterized by very low TEM resistivity of $<0.45 \Omega \mathrm{m}$, and a little higher in some places. From 2005 to 2008 new 8-10 sinkholes have formed north of the southern part of the area that is seen as 

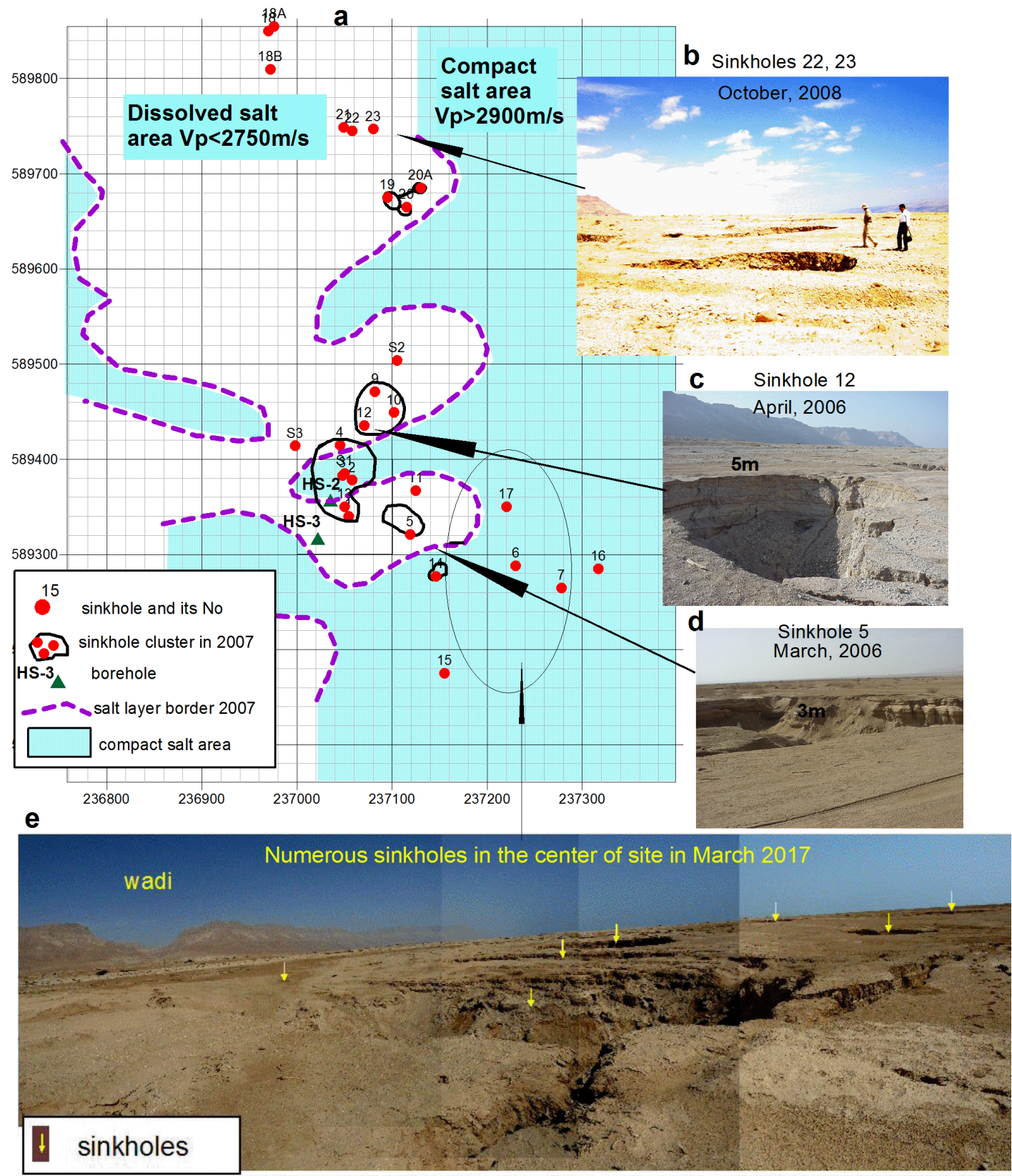

Fig. 11. a) Salt distribution map through the Nahal Hever south area based on $V_{p}$ for 2007. The examples of sinkhole images are shown: b) northern sinkholes (October, 2008); c-d) sinkholes 12 and 5 (April and March 2006, respectively) some north of the NHS center; e) the view of the NHS center in March 2017.

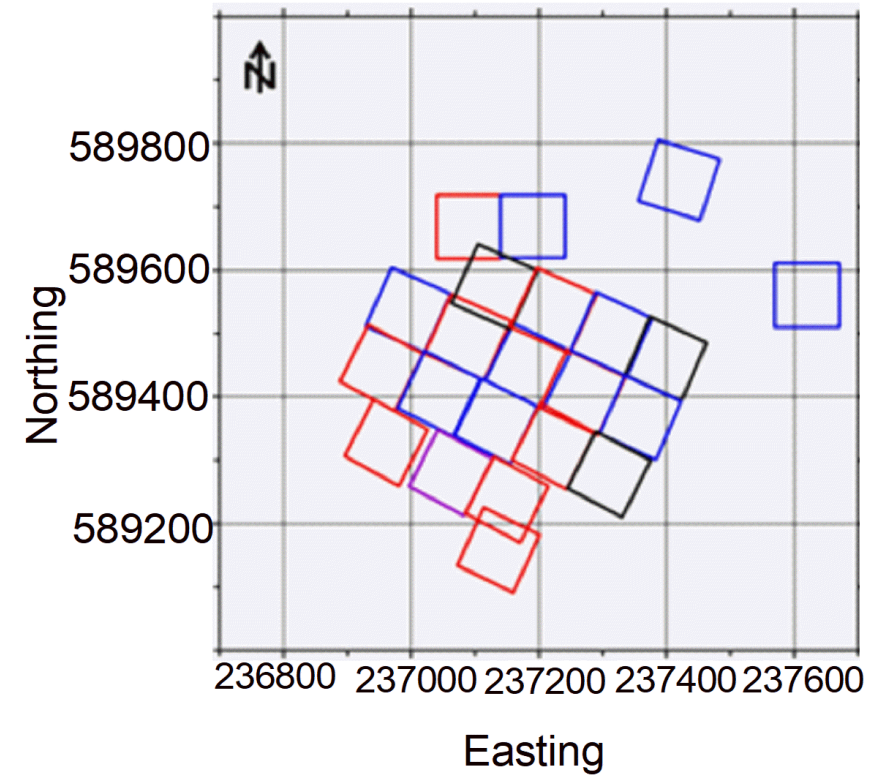

Fig. 12. Location of MRS loops in the Nahal Hever south site. low resistivity area of $0.5-0.8 \Omega m$ (Fig. 14b). Further sinkholes were formed in the eastern and northern direction, but no sinkholes have developed at the south of the NHS area. During 2009 - 2013 sinkholes fill the central part of the area and also form to the east (Fig. 14c). The resistivity of this area is similar to the northern one $(0.5-0.8 \Omega \mathrm{m})$. Finally, in Fig. $14 \mathrm{~d}$ all sinkholes formed in the NHS area are presented. We have added also cluster of sinkholes to the general map (Fig. 14d). These conclusions are reflected in graphs of sinkhole formation in southern, northern and the entire NHS area (Fig. 15). Observations have shown that since 2003-2004 the number of new sinkholes in the Nahal Hever area diminished, whereas the number of sinkholes in the northern part of the area constantly increased. Around the area, TEM monitoring revealed that the salinity of groundwater did not vary (Ezersky et al., 2008). This result is confirmed by borehole monitoring of water salinity done by GSI (Yechieli et al., 2010). 


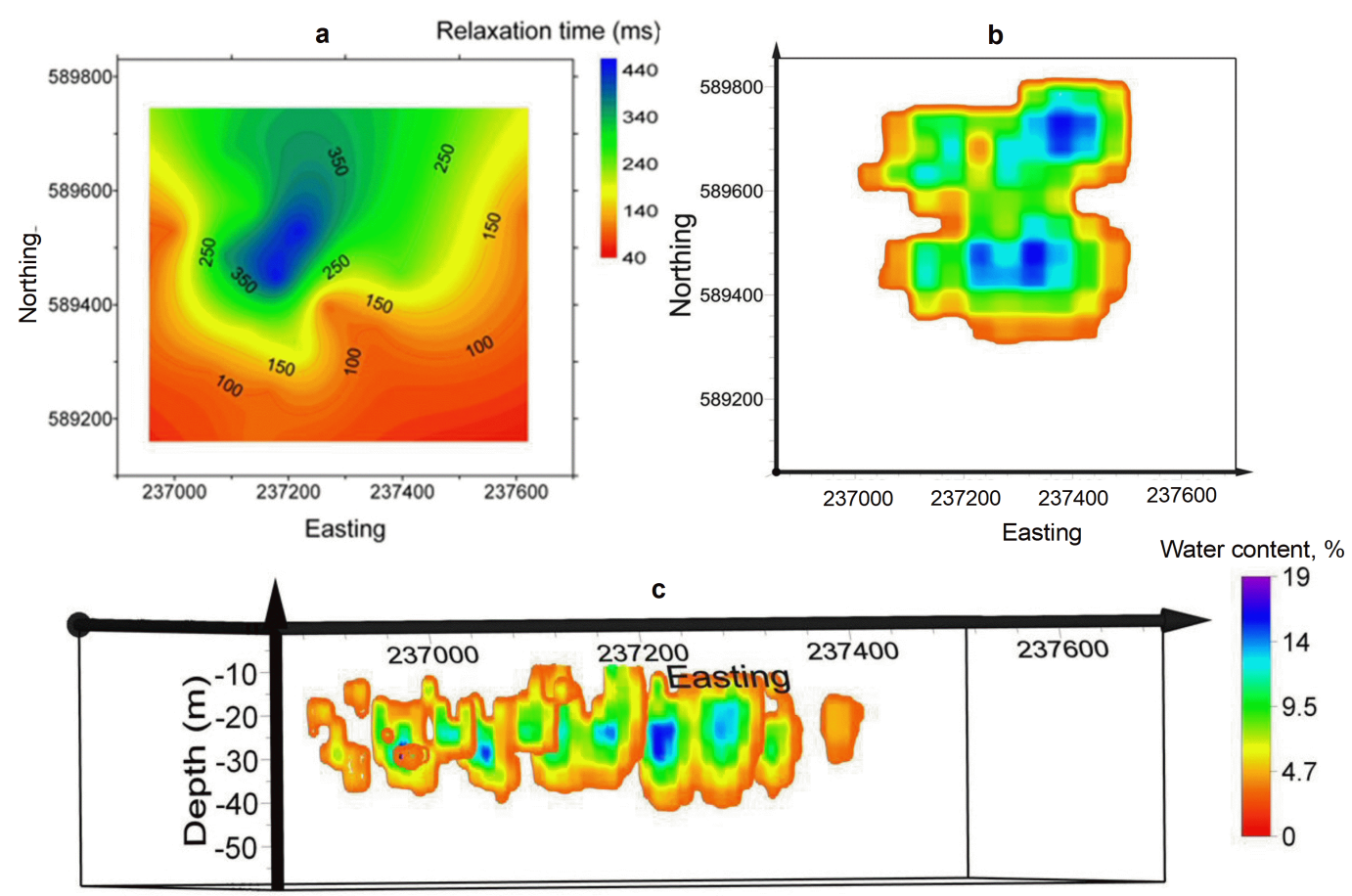

Fig. 13. 3D-SNMR results in the Nahal Hever site: a) Map of the relaxation time T1 derived from 3D-SNMR inversion; b) map of the water content distribution in at a depth of $26 \mathrm{~m}$, and c) variations of the water content within investigated area.

\section{a. 1998 - 2004}

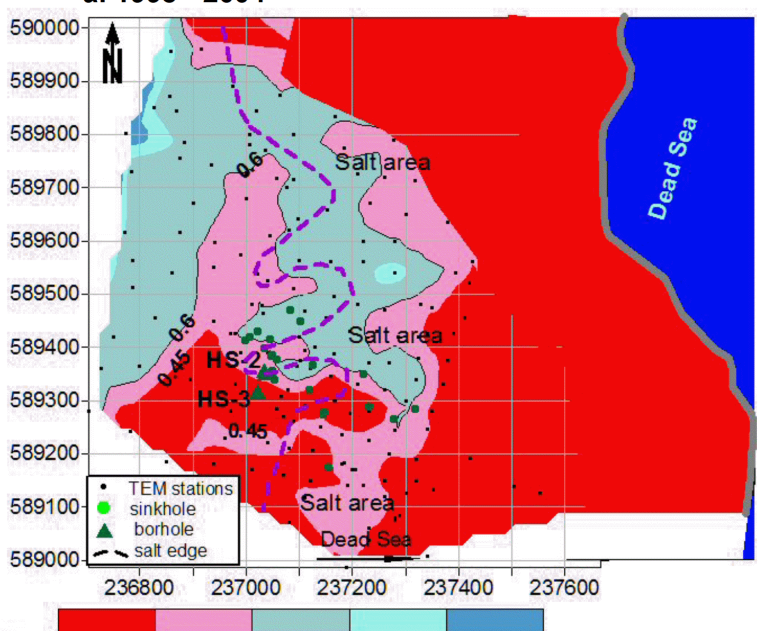

$\Omega m 0 \quad 0.45 \quad 0.6 \quad 0.86 \quad 1$

Bulk resistivity, $\rho_{x}$

\section{C. $2009-2013$}

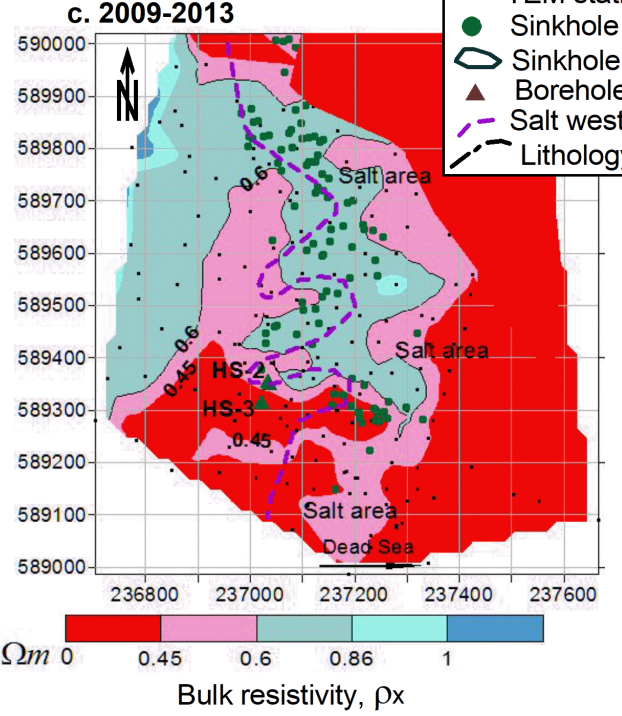

\section{b. 2005-2008}

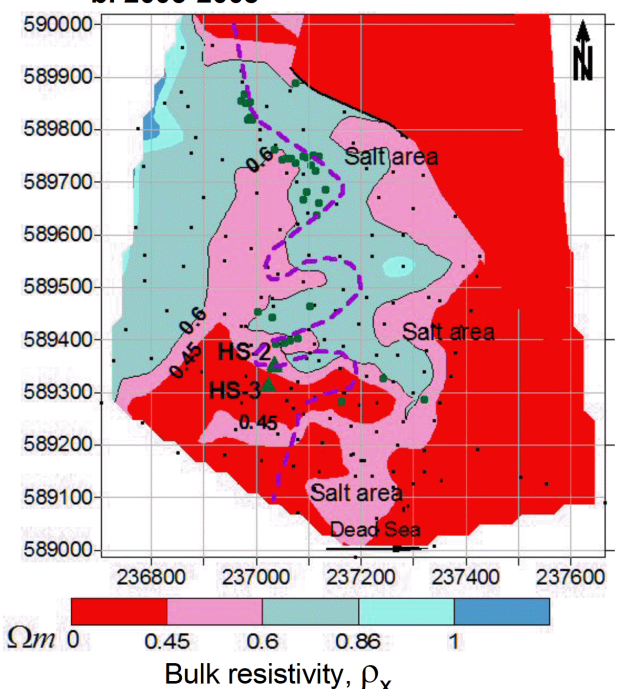

d.1998 -2013

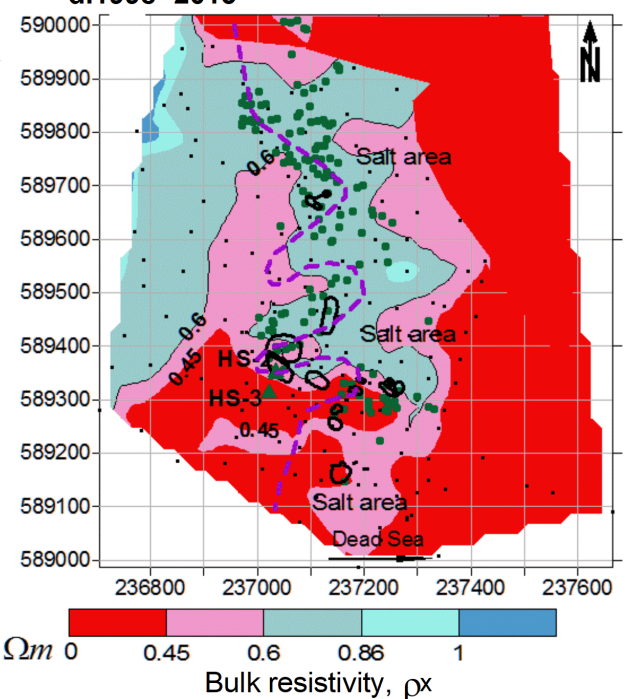

Fig. 14. Distribution of sinkholes throughout NHS area in the different periods of time. a) Sinkholes formed from 1998 to 2004; b) 2005-2008; c) 2009 - 2013; d) 1998 - 2013, clusters are also shown (Database of the Tamar Regional Council, Ein Boqeq, Israel with permission to publish). 


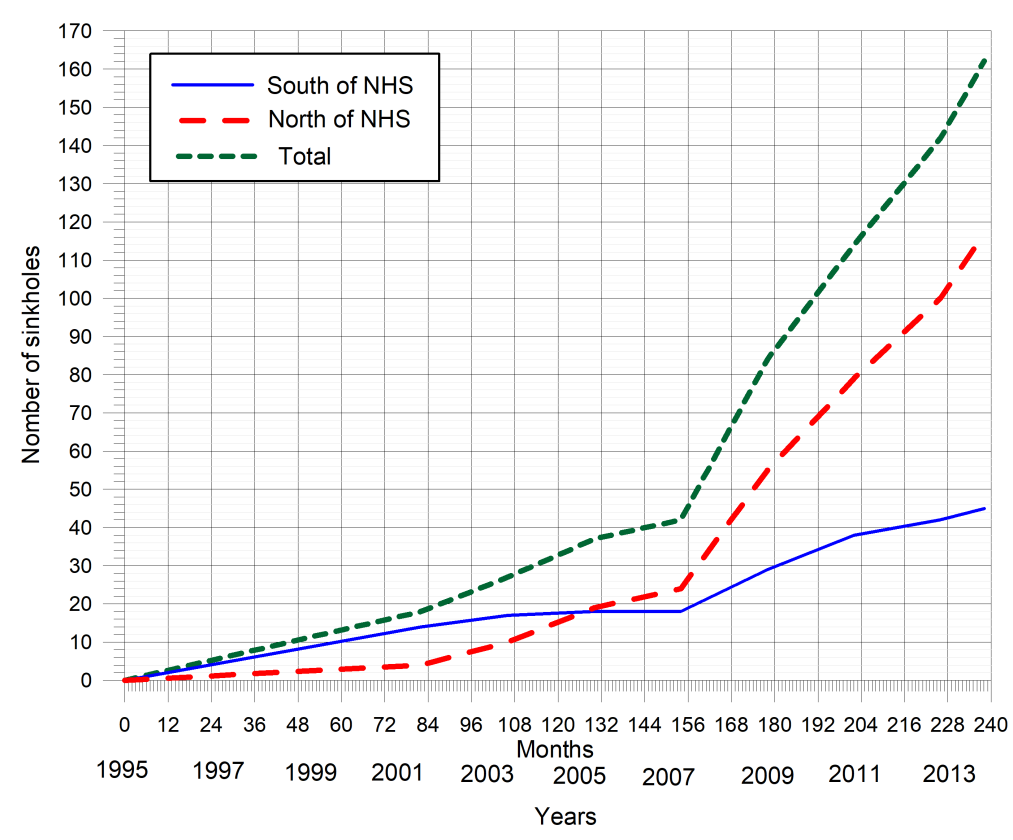

Fig. 15. Accumulative sinkhole development through the southern, northern and entire the Nahal Hever south area.

It should be noted that since 2007 sinkhole development in the southern part has slowly increased. This latter phenomenon might have been caused by the lowering of the groundwater level that will be discussed below.

\section{DISCUSSION}

\section{Salt layer as base for evaporation karst}

Mechanisms of sinkhole formation.

Based on the above analysis one can conclude that the pattern of sinkhole development along the salt edge is repeated (with small variations) in all studied sites in Israel and Jordan (Ezersky et al., 2013b). In the western DS shore it has been confirmed by numerous boreholes and seismic refraction studies and this pattern is nowadays accepted by geologists (Yechieli et al., 2016, Fig. 9). It means that sinkholes can be formed along the salt edge and, probably, no second line of sinkholes can arise in future along faults, as predicted by Abelson et al. (2003). In the Ghor Al-Haditha area mentioned above, seismic studies carried out by different researchers during 2003-2007 using various methods (in general, supporting investigations of El-Isa et al., 1995) enable us to predict the salt layer presence at a depth of 40-50 $\mathrm{m}$ and to accept the suggestions of Taqieddin et al. (2000) on the salt presence in the shallow part of the geological section.

The sinkhole layouts through the Ghor Al-Haditha area are shown in Fig. 10b. One can see that sinkholes are arranged along the tortuous line extended from the north-east to the south-west of the area. Note that the line of sinkholes slowly migrates toward the DS, especially, in the northern part of the area.

It is still not clear how the model can explain the fact that there practically was no sinkhole prior to the 1980s (before 1980 only 1-2 sinkholes per year were registered; personal communications with Arie Gilat), sinkholes slowly appeared in the 1980s and later on increasingly developed (Fig. 2). How can we explain the lack (very limited number) of sinkholes between the 1960s and the 1980s while the conditions were more or less the same than nowadays. It intuitively seems that resolving this problem relies on taking into account preexisting caverns in the salt layer as suggested by Legchenko et al. (2008c). Such sinkholes were discovered during drilling in different sites of the western shores (Yechieli et al., 2006; 2016). Nowadays, it is understandable that DS groundwater is, practically, always undersaturated and it keeps more or less the potential to dissolve salt, as long as water circulates (Ezersky \& Frumkin, 2017). Drop and rise of the DS level violates the balance of forces acting on salt from above and in caves inside and disrupts the stability of the system. Generating and checking a hydraulic-mechanical model of sinkhole formation is a problem for future investigations.

\section{Seismic reflection study using S-waves}

The results of German researchers carried out recently in the Ghor Al-Haditha area are in contradiction with the earlier discussed results. S-wave seismic reflection studies carried out in the framework of the 'Deserve' project (Krawczyk et al., 2015; Kottmeyer et al., 2016; Polom et al., 2016) have suggested an absence of a salt layer acting as a reflector at a depth of less than approximately 40-50 m. Unfortunately, they were not published in scientific literature and, therefore, can be subjected only to preliminary discussion. Polom et al. (2016) write "Since evaluation of both hypothesis by new drilling could not be carried out due to safety reasons and permissions, it remained unclear which hypothesis (salt dissolution or piping one - our comment) is valid for the investigation site". Regrettably these authors did not perform seismic refraction surveys in support to drilling. It would essentially either have supported or rejected conclusions on salt layer existence.

In our opinion, there can be two reasons explaining these results of the seismic reflection. The first reason is based on sensitivity of the method to subsurface heterogeneity. Polom et al. (2016) note that the reflection patterns indicate destabilized subsurface zones by "a weak reflection response below $40 \mathrm{~m}$ depth", and stable subsurface zones by stronger reflection responses. The quality of the reflection data is a key point of the study. Shear-wave velocities strongly depend on presence of heterogeneities in shallow sediments. This situation is typical in areas of subrosion-induced sinkholes, where destabilization processes take place continuously and over long time periods (Krawczyk et al., 2012, p. 140). This is a case of the Ghor Al-Haditha area (Al-Halbouni, 2017). Another limitation is quoted by Krawczyk et al. (2012, p. 140). In general, the NMO-correction approach for velocity model building depends on the presence of reflective elements in the subsurface. If there are only weak or strongly discontinuous reflections, the derivation of a proper velocity function is limited. Thus, conditions seem to be also characteristic for this site. All doubts 
might be resolved in articles including presentation of field materials and description of the data analysis.

Secondly, the salt layer can be, simply, degraded as was noted by Bodet et al. (2010). As we have pointed out above, seismic refraction and MASW investigations were carried out during 2003-2007, whereas seismic reflection studies were conducted in late 2013-2014. In this case surface erosion, can start in such areas, as was mentioned above in this section in Fig. 10e.

\section{Comments to Al-Halbouni et al. (2016) piping model}

Here, we should address some recent studies which disagree with our model. Al-Halbouni et al. (2017) suggested a new sinkhole development mechanism in the Ghor Al-Haditha area based on excellent data acquired applying innovative techniques based on combining photogrammetry with satellite image analysis. Their model is based on data of two boreholes drilled in the Ghor Al-Haditha area (E1-Isa, 1995), and requires the presence of a thick mud layer with salt lenses under sandy gravel sediments. Two boreholes in the area drilled to $\sim 50 \mathrm{~m}$ did not reveal neither salt nor this thick mud layer. Al-Halbouni et al. (2016) with a reference to Polom et al. (2016) suggest that there is simply no salt layer in the Ghor Al-Haditha area. We have mentioned above the conclusion of Polom et al. (2016). Thus, the model is based on unverified data of boreholes and seismic reflection data not revealing the salt layer detected by other investigators (Abueladas \& Al-Zoubi, 2004; Dhemaied, 2007; Bodet et al., 2010, Camerlynck et al., 2012; Ezersky et al., 2013a). Moreover, we did not find any evidences of salt crystalline presence in the clay (mud) or in boreholes (El-Isa et al., 1995; Taqieddin et al., 2000; Mahasneh, 2004; Khlaifata et al., 2010) although in the first case analysis was carried out with a microscope. Thus, the model suggested by Al-Halbouni et al. (2017) is by its origin a plausible one because it is based on limited geological and geophysical data. All missing data should be verified and addressed to substantiate this model based on piping mechanism (Al-Halbouni et al., 2017). To confirm their suggested model, the underground water flow could be marked by hydrological tracers (Kendall \& McDonnell, 1998).

\section{Comments to universality of sinkhole "dissolution front" model}

Abou Karaki et al. (2016) have discovered from the Corona pictures (satellite based technique) a sinkhole zone located south of the Sedom Mt. (salt dome) active since at least from the end of the 1960s. Authors affirm that "even if this zone is found above the edge of the salt layer, its dynamics cannot be explained by a moving dissolution front since that part of the lake dried-up later in the 1970s, then was filled again artificially". The site of these sinkholes attests to the fact that (whatever the conditions) the Dead Sea shores are prone to dissolution and reactive to variations in the hydrogeological setting. This is a crucial point to keep in mind when dealing with problems related to the base level fluctuations there (drop or rise)". It is difficult to discuss this affirmation. There are different types of sinkholes in the DS southern basin. There are sinkholes formed in the dam body, in asphalt cover of the route \#90, in the DS southern basin, etc. Ezersky \& Frumkin (2013) consider sinkholes formed in the specific hydrogeological conditions describing most of the sinkholes along the DS shores. Obviously, appearance of these sinkholes is associated with the edge of the salt layer located at a depth to $50 \mathrm{~m}$ from surface. We agree that the relationship of sinkholes presented by Abou Karaki et al. (2016) to the dissolution front is a doubtful one. It can be explained by the surface dissolution of the DS shores. It can be associated also with the salt of the Sedom Mt. At all, this phenomenon should be investigated by both space observations and by surface geophysics.

\section{Temporal development of sinkholes in the Nahal Hever South site}

As we have discussed above, there are differences in resistivity revealed between the southern and northern parts of the NHS site. This difference is linked rather to the variation of lithology than to the salinity of the groundwater (Legchenko et al., 2009). Ezersky $\&$ Frumkin (2017) have shown that at the same bulk resistivity, aggressiveness of the groundwater with respect to salt is sufficiently different in sandygravel sediments and lime-carbonates. This fact can be explained by different porosity: Lime-carbonate sediments have higher porosity compared with sandygravel ones, and at the same time, water salinity has a lower resistivity compared with sandy sediments.

The aforementioned physical peculiarities can explain why sinkhole formation in the southern part of NHS composed of silt was more intensive at the first stage of this process. At the same time, the 3D-SNMR method has revealed the higher water content at the north of the area that is defined by relaxation time $T_{1}$ (Fig. 13a) and has predicted a promotion of sinkholes to the north of the area. One can see in Fig. 14 that sinkholes up to 2008 were formed along the salt edge. Perhaps, the salt edge line was also modified because of dissolution. Then, the spatial sinkhole distribution was dissipated to the east of the salt edge.

To estimate the groundwater level temporal variation in the NHS area we can use results of the TEM monitoring of the saline water $(1 \Omega m)$ interface (see Ezersky et al., 2011) measured during 19992012 (Ezersky et al., 2006). The example of the measurement of DS brine depth using TEM sounding is shown in Fig. 16a. The depth is measured using variation of the groundwater $1 \Omega m$ interface $(H$ in Fig. 16a). The long-term variations of the $1 \Omega m$ interface and DS level versus time are presented in Fig. 16b (DS level data see Fig. 2).

It follows from the graphs that the ground water table varies in accordance to the DS level at a rate of $\sim 0.7 \mathrm{~m} / \mathrm{yr}$. This evaluation is supported by monitoring of Yechieli et al. (2010) who have shown that groundwater level in the DS coast boreholes is lowering at the same rate of the DS level. The amount of groundwater level drop in relation to that of the Dead Sea is controlled by the aquifer's permeability 
and by the distances from the DS shoreline. Groundwater level drop is greater and is detected more inland in high-permeability alluvial fan areas as compared to low-permeability areas. Analysis of data from the borehole $\mathrm{BH}-3 \mathrm{a}$ located in the Nahal Arugot area $\sim 900 \mathrm{~m}$ of the shoreline indicates that the groundwater table is lowering at a rate of $0.5 \mathrm{~m} / \mathrm{yr}$. For other boreholes of the Ein Gedi and Nahal Arugot areas, the rate of groundwater table lowering is in the order of $0.8 \mathrm{~m} / \mathrm{yr}$.

Thus, we can estimate the groundwater table level in the NHS site as shown in Table 5. The estimation has been carried out in a presumption that the groundwater table level has varied with a constant rate of $0.7 \mathrm{~m} / \mathrm{yr}$. Results of this estimation are compared in Table 5. For a period of 15.5 years at a rate of $0.7 \mathrm{~m} / \mathrm{yr}$ the ground water level lowered $\sim 11 \mathrm{~m}$, e.g., to 1 January 2017 it reached elevation of $-422 \mathrm{~m}$, that is $5 \mathrm{~m}$ under the salt layer top (which is located at $-417 \mathrm{~m})$.

Thus, the process of sinkhole formation led probably to a new stage of salt karstification by downward vadose flow from the ephemeral streams (Ezersky et al., 2011; Frumkin et al., 2011). This process causes surface erosion depending on the salt top cover (marl or sand-gravel) location. A view to the center of the Nahal South area in March 2017 is shown in Fig. 11 (lower photo). a

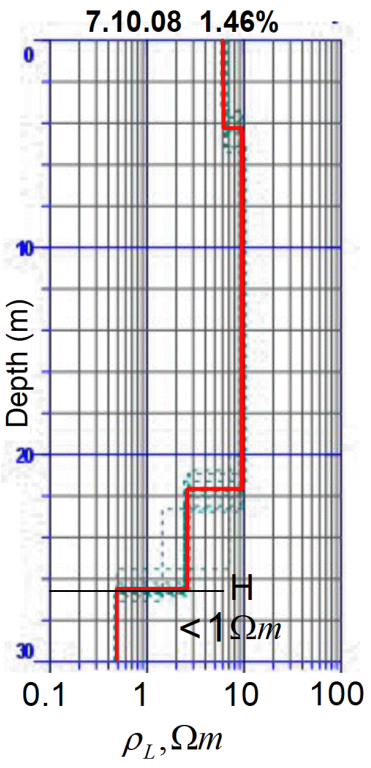

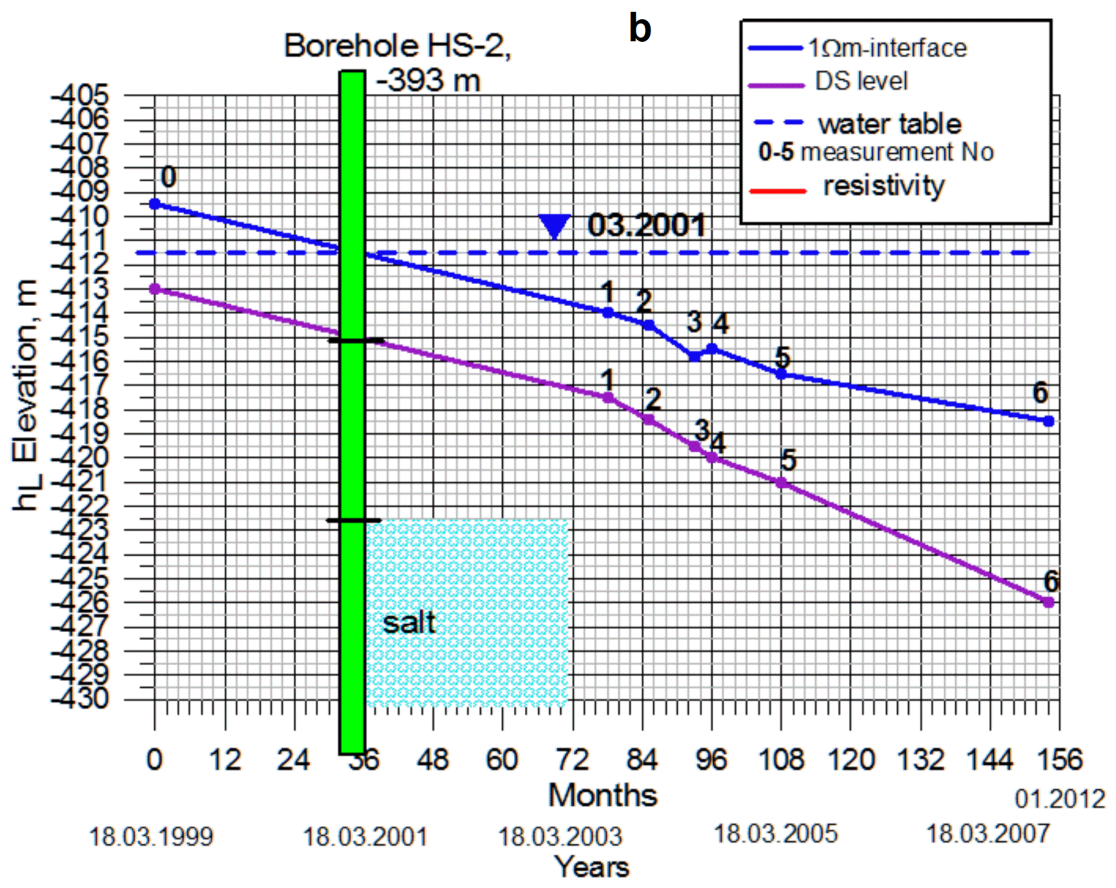

Fig. 16. Long-term variations of the groundwater table depth $\mathrm{H}$ and the DS level. a) Example of the saline groundwater depth determination using TEM sounding; b) Variation of $1 \Omega \mathrm{m}$ interface (blue line) and the DS level (lila graph) versus time (Ezersky et al., 2006a, data of GSI). $\mathrm{H}$ - is $1 \Omega m$ interface characterizing resistivity of the DS brine.

Table 5. Lowering of groundwater level with respect to salt layer top.

\begin{tabular}{|c|c|c|c|c|c|c|c|}
\hline Site & $\begin{array}{c}\text { Borehole } \\
\text { number }\end{array}$ & $\begin{array}{c}\text { Surface } \\
\text { elevation }\end{array}$ & $\begin{array}{c}\text { Salt**) } \\
\text { elevation }\end{array}$ & $\begin{array}{c}\text { GWT**) } \\
\text { elevation }\end{array}$ & $\begin{array}{c}\text { Data of } \\
\text { measurement }\end{array}$ & $\begin{array}{c}\text { Calculated } \\
\text { elevation**) } \\
\mathbf{1 . 0 1 . 2 0 1 7}\end{array}$ & $\begin{array}{c}\text { GWT level } \\
\text { Relatively to } \\
\text { salt top }\end{array}$ \\
\hline NHS $^{*}$ & HS-2 & -393 & -417 & -411 & 21.06 .2001 & -422 \\
at drilling
\end{tabular}

* Sites are denoted: NHS - Nahal Hever South, (see Fig. 7 for site location); ** salt top and Groundwater Table (GWT) elevation, respectively in borehole at drilling (Yechieli et al., 2004); *** approximate elevation of GWT calculated in suggestion that water table in boreholes has varied in correspondence to the DS level variations as $-(0.5-0.8 \mathrm{~m})$ per year in the northern basin (Yechieli et al., 2010) and $+0.2 \mathrm{~m}$ per year in southern one (Yechieli et al., 2001); DS level is given in accordance to the Geological Survey of Israel (GSI) data.

\section{CONCLUSIONS}

1. Application of surface geophysical methods allowed us: delineating location of the salt deposits, mapping groundwater salinity, performing in-situ and laboratory measurements of the shear and longitudinal wave velocities $\left(V_{p}\right.$ and $\left.V_{s}\right)$ corresponding to different geological formations typical for the DS area, detecting water saturated caverns and estimating their volume (see Table 4).

2. The properties of the DS soils and salt were studied in-situ and in laboratory (Table 2). This additional knowledge may contribute to more accurate numerical modeling of the sinkhole development in the Dead Sea coast.
3. Geophysical results suggest that sinkholes preferentially appear along the salt edge, exposed to brackish groundwater flow. This observation was confirmed (with small variations) in all investigated sites both in Israel and Jordan (Ezersky et al., 2013b).

4. The existence of different mechanisms of sinkhole development point to the complexity of the phenomenon and our geophysical results support some of the models. Some other models have not been confirmed by field results.

5. We recommend to use $3 \mathrm{D}-\mathrm{SNMR}$ for locating water-filled caverns and estimation of their volume, evaluation of groundwater aggressiveness using TEM, Seismic refraction and MASW method for salt layer mapping and evaluation of its karstification. 


\section{ACKNOWLEDGEMENTS}

This work was made possible through support provided by the U.S. Agency for International Development, under the terms of Award No M27-050 and NATO's Science for Peace Program (project No. 981128). We thank the Ministry of Energy and Water Resources of Israel for supporting this investigation. Many thanks to the Geophysical Institute of Israel. The field crews of the Geophysical Institute of Israel and Al-Balqa Applied University were working in the difficult and dangerous conditions of the Dead Sea sinkhole areas. We thank our colleagues from Paris 6 University C. Camerlynck, L. Bodet, A. Dhemaied for permission to reuse their data. We are grateful to C. Krawczyk for materials of S-wave survey in the area. We are grateful also to Tamar Regional Council for support of our study and providing us with DS sinkhole database in Israel. Thanks to A. Abueladas who provided us with sinkhole database 2016 in Jordan. Y. Yechieli supported us with database on variations of groundwater table in boreholes and GSI send us data on variations of the DS level. We are grateful to two anonymous reviewers and the Editor for the constructive and comprehensive review of our manuscript.

\section{REFERENCES}

Abelson M., Gidon B., Shtivelman V., Wachs D., Raz E., Crouvi O., Kurzon I. \& Yechieli Y., 2003 - Collapsesinkholes and radar interferometry reveal neotectonics concealed within the Dead Sea basin. Geophysical Research Letters, 30 (10): 1545.

https://doi.org/10.1029/2003GL017103

Abelson M., Yechieli Y., Crouvi O., Baer G., Wacks D., Bein A. \& Shtivelman V., 2006 - Evolution of the Dead Sea sinkholes. In: Enzel Y., Agnon A. \& Stein M. (Eds.), New frontiers in Dead Sea Paleoenvironmental research. Geological Society America Special Paper, 401: 241-253. https://doi.org/10.1130/2006.2401(16)

Abelson M., Yechieli Y., Aksinenko T., Pinski V. \& Baer B., 2013 - Microseismic monitoring of concealed sinkholes activity at Mineral Beach, Dead Sea, Israel. GSI Report GSI/29/2013.

Abou Karaki N. \& Closson D., 2012 - Field Guide. EAGE Workshop on the Dead Sea sinkholes: Amman, Jordan. 23-25 September 2012.

http://www.eage.org/images/cms/files/Conferences/ Field\%20Guide\%20-\%20color\%20-\%20min\%20size.pdf

Abou Karaki N., Fiaschi S. \& Closson D., 2016 Sustainable development and anthropogenic induced geomorphic hazards in subsiding areas. Earth Surface Processes and Landforms, 41 (15): 2282-2295.

https://doi.org/10.1002/esp.4047

Abueladas A. \& Al-Zoubi A., 2004 - The application of a combined geophysical survey (GPR and seismic refraction) for mapping sinkholes in Ghor Al-Haditha Area, Jordan. Fall Meeting Supplement. EOS Transactions, American Geophysical Union, 85, p. 47 (Abstract GP11A-0825).

Al-Halbouni D., Holohan E.P., Saberia L., Alrshdan H., Sawarieh A., Closson D., Walter T.R. \& Dahm T., 2017 - Sinkholes, subsidence and subrosion on the eastern shore of the Dead Sea as revealed by a close-range photogrammetric survey. Geomorphology, 285: 305-324. https://doi.org/10.1016/j.geomorph.2017.02.006
Al-Zoubi A. \& ten Brink U.S., 2001 - Salt diapir in the Dead Sea and their relationship to Quaternary Extensional Tectonics. Marine and Petroleum Geology, 18: $779-797$.

https://doi.org/10.1016/S0264-8172(01)00031-9

Al-Zoubi A., Abueladas A-R., Camerlynck C., Al-Ruzouq R, Al-Rawashdeh S., Ezersky M. \& Ali W., 2007 - Use of $2 D$ multi electrodes resistivity imagining for sinkholes hazard assessment along the eastern part of the Dead Sea, Jordan., American Journal of Environmental Sciences 3 (4): 229-233.

https://doi.org/10.3844/ajessp.2007.230.234

Al-Zoubi A., Eppelbaum L, Abueladas A, Ezersky M. \& Akkawi E., 2013 - Removing regional trends in microgravity in complex environments: Testing on $3 D$ model and field investigations in the eastern Dead Sea coast (Jordan). International Journal of Geophysics, 2013: 341797. https://doi.org/10.1155/2013/341797

Arandjelovi D., 1969 - A possible way of tracing groundwater flows in karst. Geophysical Prospecting, 17 (4): 404-418.

https://doi.org/10.1111/j.1365-2478.1969.tb01986.x

Arkin Y. \& Gilat A., 2000 - Dead Sea sinkholes- an everdeveloping hazard. Environmental Geology, 39 (7): 711-722. https://doi.org/10.1007/s002540050485

Barsukov P., Fainberg E. \& Khabensky E., 2015 - Shallow investigations by TEM-FAST technique: methodology and examples. In: Spichak V. (Ed.), Electromagnetic sounding of the Earth's interior: Theory, modeling, practice ( $2^{\text {nd }}$ ed.). Methods in Geochemistry and Geophysics, 40: 55-77.

https://doi.org/10.1016/S0076-6895(06)40003-2

Bartov Y., Agnon A., Enzel Y. \& Stein M. 2006 - Late Quaternary faulting and subsidence in the central Dead Sea basin. Israel Journal Earth Sciences 55: 17-31.

Beck B.F., 2003 - Sinkholes and the Engineering and Environmental Impacts of Karst. Geo Technical Special Publication. No. 122, Reston, VA, 737 p.

Beck B.F. \& Herring J.G., 2001 - Geotechnical and environmental applications of karst geology and hydrology. In: Proceedings of the $8^{\text {th }}$ Multidisciplinary Conference on Sinkholes and the Engineering and Environmental Impacts of Karst. Rotterdam, A.A. Balkema, $437 \mathrm{p}$.

Begin B., Ehrlich A. \& Nathan Y., 1974 - Lake Lisan the Pleistocene precursor of the Dead Sea. Geological Survey of Israel Bulletin, 63: $30 \mathrm{p}$.

Ben Avraham Z., 2001 - The Dead Sea - a unique global site. European Review, 9 (4): 437-444. https://doi.org/10.1017/S1062798701000400

Beyth M., 2007 - The Red Sea and the MediterraneanDead Sea canal project. Desalination, 214: 364-370. https://doi.org/10.1016/j.desal.2007.06.002

Bodet L., Galibert P.Y., Dhemaied A., Camerlynck C. \& Al-Zoubi A., 2010 - Surface-wave profiling for sinkhole hazard assessment along the eastern Dead Sea shoreline, Ghor Al-Haditha, Jordan. $72^{\text {th }}$ EAGE Conference \& Exibition incorporating EUROPEC 2010, Barcelona, Spain, 14-17 June, 2010, M027, 4 p.

Boucher M., Girard J.F., Legchenko A., Baltassat J.M., Dörfliger N. \& Chalikakis K., 2006 - Using 2D inversion of magnetic resonance soundings to locate a water-filled karst conduit. Journal of Hydrology, 330 (3-4): 413-421. https://doi.org/10.1016/j.jhydrol.2006.03.034

Boucher M., Favreau G., Nazoumou Y., Cappelaere B., Massuel S. \& Legchenko A., 2012 - Constraining groundwater modeling with magnetic resonance soundings. Ground Water, 50 (5): 775-784. https://doi.org/10.1111/j.1745-6584.2011.00891.x 
Buthens J., Filippi M., Asadi N., Zare M., Slechta S. \& Churackova Z., 2009 - Surficial deposits on salt diapirs (Zagros Mountains and Persian Gulf Platform, Iran): characterization, evolution, erosion and the influence on landscape morphology. Geomorphology, 107: 195-209. https://doi.org/10.1016/j.geomorph.2008.12.006

Camerlynck C.M., Abueladas A., Al-Ruzouq R., Al-Zoubi A., Boucher M., Bodet L., Dhemaied A. \& Galibert P.Y., 2012 - Geophysical assessment of sinkhole hazard evaluation at Ghor Haditha (Dead Sea, Jordan). EAGE Workshop on Dead Sea Sinkholes - Causes, Effects \& Solutions 23-25 September 2012, Amman, Jordan, DS07, 4 p.

Charrach J., Goretsky I. \& Frydman S., 2007 Geotechnical studies of soils from an evaporate environment in Israel. In: Proceedings: $5^{\text {th }}$ International Congress on Environmental Geotechnics, Cardiff, Wales 1. Thomas Telford, London: 407-414.

Closson D., 2005 - Structural control of sinkholes and subsidence hazards along the Jordanian Dead Sea coast. Environmental Geology 47: 290-301.

https://doi.org/10.1007/s00254-004-1155-4

Closson D. \& Abou Karaki N., 2009 - Salt karst and tectonics: sinkholes development along tension cracks between parallel strike-slip faults, Dead Sea, Jordan. Earth Surface Process and Landforms 34 (10): 14081421. https://doi.org/10.1002/esp.1829

De Waele J., Picotti V., Zini L., Cucchi F. \& Forti P., 2009 - Karst phenomena in the Cordillera de Sal (Atacama, Chile). In: Rossi P.L. (Ed.), Geological constraints on the onset and evolution of an extreme environment: the Atacama area. Geoacta, Special Publication, 2: 113-127.

Dhemaied A., 2007 - Tomographie seismique d'une zone de subsidence (Sinkhole zone, Ghor Al-Haditha, Jordanie). Unpublished MS Report, Paris 6 University, Paris (in French).

DS sinkhole database 1998-2016. Unpublished reports of the Tamar Regional Council (from permission of authors).

El-Isa Z., Rimawi O., Jarrar G., Abu-Karaki N., Taqieddin S., Atalah M., Abderahman N. \& Al-Saed A., 1995 Assessment of the hazard of subsidence and sinkholes in Ghor Al-Haditha area. Report submitted to Jordan Valley Authority. University of Jordan, Amman: 141 p.

Eppelbaum L.V., 2007 - Localization of Ring Structures in Earth's Environments. Journal of the Archaeological Society of the Slovakian Academy of Sciences, 41: 145-148.

Eppelbaum L., 2010 - Archaeological geophysics in Israel: past, present and future. Advances in Geosciences, 24: 45-68. https://doi.org/10.5194/adgeo-24-45-2010

Eppelbaum L.V., 2015a - Interpretation of microgravity and magnetic data for delineation of subsurface salt bodies in unfavourable $S / N$ ratio conditions. Proceedings of the 2015 SAGEEP Conference, Austin, Texas, USA, 28 (1): 686-695.

Eppelbaum L.V., 2015b - Quantitative interpretation of magnetic anomalies from bodies approximated by thick bed models in complex environments. Environmental Earth Sciences, 74: 5971-5988.

https://doi.org/10.1007/s12665-015-4622-1

Eppelbaum L.V. \& Khesin B.E., 2004 - Advanced 3-D modelling of gravity field unmasks reserves of a pyritepolymetallic deposit: A case study from the Greater Caucasus. First Break, 22 (11): 53-56.

Eppelbaum L.V., Khesin B.E \& Itkis S.E., 2001 - Prompt magnetic investigations of archaeologica remains in areas of infrastructure development: Israeli experience. Archaeological Prospection, 8 (3): 163-185.

https://doi.org/10.1002/arp.167
Eppelbaum L.V., Ezersky M., Al-Zoubi A., Goldshmidt V. \& Legchenko A., 2008 - Study of the factors affecting the karst volume assessment in the Dead Sea sinkhole problem using microgravity field analysis and $3 D$ modeling. Advances in Geosciences, 19: 97-115.

https://doi.org/10.5194/adgeo-19-97-2008

Ezersky M., 2006 - The Geophysical properties of the Dead Sea salt applied to the sinkhole problem. Journal of Applied Geophysics, 58 (1): 45-58. https://doi.org/10.1016/j.jappgeo.2005.01.003

Ezersky M., 2008 - Geoelectric structure of the Ein Gedi sinkhole occurrence site at the Dead Sea shore in Israel. Journal of Applied Geophysics, 64: 56-69. https://doi.org/10.1016/j.jappgeo.2007.12.003

Ezersky M., 2011 - Improvement of the seismic refraction methods for mapping of the buried salt layers along the Dead Sea shoreline. GII Report No. 211/486/09, Lod, Israel, $24 \mathrm{p}$.

Ezersky M., 2013 - Sinkhole hazard. Part VI. Geotechnical and geophysical properties of soils in the Dead Sea sinkhole problem. GII Report MERC_6-M27-050/2013, July, 2013, 42 p.

Ezersky M. \& Frumkin A., 2013 - Faults-dissolution front relations and the DS sinkholes problem. Geomorphology, 201: 35-44.

http://dx.doi.org/10.1016/j.geomorph.2013.06.002

Ezersky M. \& Frumkin A., 2017 - Evaluation and mapping of Dead Sea coastal aquifers salinity using Transient Electromagnetic (TEM) resistivity measurements. Comptes Rendus Geosciences, 349 (1): 1-11. https://doi.org/10.1016/j.crte.2016.08.001

Ezersky M.G. \& Goretsky I., 2014 - Velocity-resistivity versus porosity-permeability inter-relations in Dead Sea salt samples. Engineering Geology, 183: 96-115. https://doi.org/10.1016/j.enggeo.2014.09.009

Ezersky M. \& Legchenko A. 2008 - Sinkhole Hazards. Part I. Mapping of the salt in sinkhole hazardous sites along western Dead Sea shore using Seismic Refraction method. NATO Programme Science for Peace, Project SfP 981128. Report No. 232/361/08. GII-IRD, 63 p.

Ezersky M. \& Legchenko A., 2014 - Quantitative assessment of In-situ salt karstification using shear wave velocity, Dead Sea. Geomorphology, 221: 150163. https://doi.org/10.1016/j.geomorph.2014.06.014

Ezersky M. \& Legchenko A., 2015 - Mapping of salt consolidation and permeability using MASW method in the Dead Sea sinkhole problem. In: Lollino G., Manconi A., Guzzetti F., Culshaw M., Bobrowsky P. \& Luino F. (Eds.), Engineering geology for society and territory. Springer, Berlin, 5: 465-469.

https://doi.org/10.1007/978-3-319-09048-1 89

Ezersky M. \& Livne E., 2013 - Geotechnical and geophysical properties of soils in the Dead Sea sinkhole problem. EAGE Annual Meeting of Near Surface Geoscience, 9-12 September, 2013, Bochum MO P13, 4 p. https://doi.org/10.3997/2214-4609.20131328

Ezersky M., Legchenko A., \& Camerlynck C. 2006 - Part III. TEM mapping of shallow aquifers and study of their link with sinkhole development in the Dead Sea coastal area of Israel. NATO Programme Science for Peace, Project SfP 981128. Report No. 232/362/08 GII- Paris 6 University-IRD, $122 \mathrm{p}$.

Ezersky M., Legchenko A., Camerlynck C. \& Al-Zoubi A., 2009 - Identification of sinkhole development mechanism based on a combined geophysical study in Nahal Hever South area (Dead Sea coast of Israel). Environmental Geology, 58 (5): 1123-1141. https://doi.org/10.1007/s00254-008-1591-7 
Ezersky M., Legchenko A., Camerlynck C., Al-Zoubi A., Eppelbaum L., Keidar S., Baucher M. \& Chalikakis K. 2010 - The Dead Sea sinkhole hazard- new findings based on a multidisciplinary geophysical study. Zeitschrift für Geomorphologie, 54 (2): 69-90. https://doi.org/10.1127/0372-8854/2010/ 0054S2-0005

Ezersky M., Legchenko A., Al-Zoubi A., Levi E., Akkawi E. \& Chalikakis K, 2011 - TEM study of the geoelectrical structure and groundwater salinity of the Nahal Hever sinkhole site, Dead Sea shore, Israel. Journal of Applied Geophysics, 75 (1): 99-112.

https://doi.org/10.1016/j.jappgeo.2011.06.011

Ezersky M., Bodet L., Akkawi E., Al-Zoubi A., Camerlynck C., Dhemaied A. \& Galibert P.-Y., 2013a - Seismic surface-wave prospecting methods for sinkhole hazard assessment along the Dead Sea shoreline. Journal Environmental and Engineering Geophysics, 18 (4): 233-253. https://doi.org/10.2113/JEEG18.4.233

Ezersky M.G., Eppelbaum L.V., Al-Zoubi A., Keydar S., Abueladas A.-R., Akkawi E. \& Medvedev B., 2013b - Geophysical prediction and following development sinkholes in two Dead Sea areas, Israel and Jordan. Environmental Earth Sciences, 70 (4): 1463-1478. https://doi.org/10.1007/s12665-013-2233-2

Ezersky M.G., Al-Zoubi A., Eppelbaum L.V., Keydar S., 2013c - Sinkhole Hazard Assessment of the Dead Sea area in Israel and Jordan: Multidisciplinary Study. Final Technical Report MERC_M27-050, 142 p.

Ezersky M.G., Eppelbaum L.V., Al-Zoubi A., Keydar S., Abueladas A.-R., Akkawi E. \& Medvedev B., 2014 Comments to publication of D. Closson and N. Abu Karaki 1365 "Sinkhole hazards prediction at Ghor Al Haditha, Dead Sea, Jordan: "Salt Edge" and "Tectonic" models contribution - a rebuttal to "Geophysical prediction and following development ...". Environmental Earth Sciences, 71 (4): 1989-1993.

https://doi.org/10.1007/s12665-013-3019-2

Ford D.C. \& Williams P.W., 2007 - Karst hydrogeology and geomorphology. Wiley, Chichester, $562 \mathrm{p}$.

https://doi.org/10.1002/9781118684986

Frumkin A., 1994 - Morphology and development of salt caves. National Speleological Society Bulletin, 56: 82-95.

Frumkin A., 1995 - Rapid entrenchment of stream profiles in the salt caves of Mount Sedom, Israel. Earth Surface Processes and Landforms 20: 139-152.

https://doi.org/10.1002/esp.3290200205

Frumkin A. \& Raz E., 2001 - Collapse and subsidence associated with salt karstification along the Dead Sea. Carbonates and Evaporites, 16 (2): 117-130. https://doi.org/10.1007/BF03175830

Frumkin A., Karkanas P., Bar-Matthews M., Barkai R., Gopher A., Shahack-Gross R. \& Vaks A., 2009a - Gravitational deformations and fillings of aging caves: the example of Qesem karst system, Israel. Geomorphology, 106: 154-164.

https://doi.org/10.1016/j.geomorph.2008.09.018

Frumkin A., Kofman L. \& Ezersky M., 2009b Improvement of the reliability of subsurface void detection, including sinkhole development, at the Dead Sea shore area by means of Ground Penetration Radar (GPR). Hebrew University - TECHNION Research and Development Foundation LTD - Geophysical Institute of Israel, Report No. MNI-ES-36-2008, 145 p.

Frumkin A., Ezersky M., Al-Zoubi A., Akkawi E. \& Abueladas A.-R. 2011 - The Dead Sea hazard: geophysical assessment of salt dissolution and collapse. Geomorphology, 134 (1-2): 102-117.

https://doi.org/10.1016/j.geomorph.2011.04.023
Frydman S., Charrash J. \& Goretsky I., 2008 Geotechnical properties of evaporate soils on the Dead Sea area. Engineering Geology, 101 (3-4): 236-244. https://doi.org/10.1016/j.enggeo.2008.06.003

Frydman S., Charrash J. \& Goretsky I., 2014 - A geotechnical study of evaporitic, lacustrine sediments in the saline environment of the Dead Sea area. Engineering Geology, 181: 309-322.

https://doi.org/10.1016/j.enggeo.2014.08.028

Galve J., Gutiérrez F., Lucha P., Guerrero J., Remondo J., Bonachea J. \& Cendrero A., 2009a - Probabilistic sinkhole modelling for hazard assessment. Earth Surface Processes and Landforms, 34 (3): 437-452.

https://doi.org/10.1002/esp.1753

Galve J.P., Gutiérrez F., Remondo J., Bonachea J., Lucha P. \& Cendrero A., 2009b - Evaluating and comparing methods of sinkhole susceptibility mapping in the Ebro Valley evaporite karst (NE Spain). Geomorphology, 111 (3-4): 160-172.

https://doi.org/10.1016/j.geomorph.2009.04.017

Garfunkel Z., 1981 - Internal structure of the Dead Sea leaky transform (rift) in relation to plate kinematics. Tectonophysics, 80: 81-108.

https://doi.org/10.1016/0040-1951(81)90143-8

Garfunkel Z., 1997 - The history and formation of the Dead Sea basin. In: Niemi T.M., Ben-Avraham Z. \& Gat J. (Eds.), The Dead Sea: The lake and its setting. Oxford University Press, Oxford, p. 36-55.

Girard J.-F., Boucher M., Legchenko A. \& Baltassat J.-M., 2007 - 2D magnetic resonance tomography applied to karstic conduit imaging. Journal of Applied Geophysics, 63 (3-4): 103-116.

https://doi.org/10.1016/i.jappgeo.2007.08.001

Goetz P.W. (Ed.), 1986 - The new Encyclopedia Britannica 3 (15 th ed.). Encyclopedia Britannica, Chicago, p. 937. http://en.wikipedia.org/wiki/List_of_bodies_of water_by_salinity

Goldman M., Gilad D., Ronen A. \& Melloul A., 1991 Mapping of sea water intrusion into the coastal aquifer of Israel by the time domain electromagnetic method. Geoexploration, 28: 153-174.

https://doi.org/10.1016/0016-7142(91)90046-F

Gutiérrez F., Cooper A. \& Johnson K., 2008 - Identification, prediction, and mitigation of sinkhole hazards in evaporite karst areas. Environmental Geology, 53: 1007-1022.

https://doi.org/10.1007/s00254-007-0728-4

Gutiérrez F., Parise M., De Waele J. \& Jourde H., 2014 - A review on natural and human induced geohazards and impacts in karst. Earth Sciences Review, 138: 6188. https://doi.org/10.1016/j.earscirev.2014.08.002

Hammer U.T., 1986 - Saline lake ecosystems of the world. Springer, Berlin.

Hertrich M., Braun M., Gunther T., Green A.G. \& Yaramanci U., 2007 - Surface nuclear magnetic resonance tomography. IEEE Transactions on Geoscience and Remote Sensing , 45 (11): 3752-3759. https://doi.org/10.1109/TGRS.2007.903829

Hertrich M., 2008 - Imaging of groundwater with nuclear magnetic resonance. Progress in Nuclear Magnetic Resonance Spectroscopy, 53 (4): 227-248.

https://doi.org/10.1016/j.pnmrs.2008.01.002

Hertrich M., Green A.G., Braun M. \& Yaramanci U., 2009 - High-resolution surface NMR tomography of shallow aquifers based on multioffset measurements. Geophysics, 74 (6): G47-G59.

https://doi.org/10.1190/1.3258342

Jenyon M.K., 1986 - Salt tectonics. Elsevier, New York, 198 p. 
Kafri U., Goldman M. \& Lang B., 1997 - Detection of subsurface brines, freshwater bodies and the interface configuration in-between by the time domain electromagnetic method in the Dead Sea Rift, Israel. Environmental Geology, 31 (1-2): 42-49. https://doi.org/10.1007/s002540050162

Kafri U. \& Goldman M., 2005 - The use of the time domain electromagnetic method to delineate saline groundwater in granular and carbonate aquifers and evaluate their porosity. Journal of Applied Geophysics, 57: 167-178. https://doi.org/10.1016/j.jappgeo.2004.09.001

Kendall C., \& McDonnell J.J. (Eds.), 1998 - Isotope tracers in catchment hydrology. Elsevier Science, Amsterdam, 839 p.

Keydar S., Pelman D. \& Ezersky M., 2010 - Application of seismic diffraction imaging for detecting near-surface inhomogeneities in the Dead Sea area. Journal of Applied Geophysics, 71 (2-3): 47-52. https://doi.org/10.1016/j.jappgeo.2010.04.001

Keydar S., Medvedev B., Ezersky M. \& Sobolevsky L., 2012 - Imaging shallow subsurface of Dead Sea area by Common Shot Point stacking and diffraction method using weighted multipath summation. Journal of Civil Engineering and Science, 1 (2): 75-79.

http://www.academicpub.org/jces/paperInfo. aspx?PaperID $=1770$

Keydar S., Medvedev B., Al-Zoubi A., Ezersky M. \& Akkawi E., 2013 - 3D Imaging of Dead Sea area using weighted multipath summation: A case study. International Journal of Geophysics, 2013: 692452. https://doi.org/10.1155/2013/692452

Khlaifata A., Al-Khashmanb O., Qutoba H. \& Oil W., 2010 - Physical and chemical characterization of Dead Sea mud. Materials characterization, 61 (5): 564-568. https://doi.org/10.1016/j.matchar.2010.02.015

Klimchouk A., 2005 - Subsidence hazards in different types of karst: evolutionary and speleogenetic approach. Environmental Geology, 48: 287-295. https://doi.org/10.1007/s00254-005-1275-5

Kottmeier C., Agnon A., Al-Halbouni D., Alpert P., Corsmeier U., Dahm T., Eshel A., Geyer S., Haas M., Holohan E., Kalthoff N., Kishcha P., Krawczyk C.M., Lati J., Laronne J.B., Lott F., Mallast U., Merz R., Metzger J., Mohsen A., Morin E., Nied M., Rödiger T., Salameh E., Sawarieh A., Shannak B., Siebert C. \& Weber M., 2016 - New perspectives on interdisciplinary earth science at the Dead Sea: The DESERVE project. Science of the Total Environment, 544: 1045-1058. https://doi.org/10.1016/j.scitotenv.2015.12.003

Krawczyk C.M., Polom U., Trabs S. \& Dahm T. 2012 Sinkholes in the city of Hamburg-New urban shearwave reflection seismic system enables high-resolution imaging of subrosion structures. Journal of Applied Geophysics, 78: 133-143.

https://doi.org/10.1016/j.jappgeo.2011.02.003

Krawczyk C. M., Polom U., Alrshdan H., Al-Halbouni D., Sawarieh A. \& Dahm T., 2015 - New process model for the Dead Sea sinkholes at Ghor Al Haditha, Jordan, derived from shear-wave reflection seismics. In: EGU General Assembly 2015. Vienna, Austria, id. 5761

Lachassagne P., Baltassat J.M., Legchenko A. \& de Gramont H.M., 2005 - The links between MRS parameters and the hydrogeological parameters. Near Surface Geophysics, 3 (4): 259-265.

https://doi.org/10.3997/1873-0604.2005021

Legchenko A., 2013 - Magnetic Resonance Imaging for groundwater. ISTE Ltd., John Willey \& Sons Ltd.. Great Britain, 158 p.

https://doi.org/10.1002/9781118649459
Legchenko A. \& Shushakov O.A., 1998 - Inversion of surface NMR data. Geophysics, 63: 75-84.

https://doi.org/10.1190/1.1444329

Legchenko A. \& Valla P., 2002 - A review of the basic principles for proton magnetic resonance sounding measurements. Journal of Applied Geophysics, 50: 3-19. https://doi.org/10.1016/S0926-9851(02)00127-1

Legchenko A., Baltassat J-M, Bobachev A., Martin C., Robin H. \& Vouillamoz J-M., 2004 - Magnetic resonance sounding applied to aquifer characterization. Ground Water, 42 (3): 363-373.

https://doi.org/10.1111/j.1745-6584.2004.tb02684.x

Legchenko A., Descloitres M., Bost A., Ruiz L., Reddy M., Girard J.F., Sekhar M., Kumar M.S.M. \& Braun J.J., 2006 - Resolution of MRS applied to the characterization of hardrock aquifers. Ground Water, 44 (4): 547-554. https://doi.org/10.1111/j.1745-6584.2006.00198.x

Legchenko A., Ezersky M., Camerlynck C. \& Chalikakis K., 2006 - Sinkhole Hazards, Part IIa. Geophysical study of shallow groundwater flow and its relationship with sinkholes development in the Dead Sea coastal area of Israel. NATO Project Science for Peace, 981128. Report No. 232/201/06 IRD-GII-Paris 6 University, 122 p.

Legchenko A., Ezersky M., Girard J-F., Baltassat J-M., Camerlynck C. \& Al-Zoubi A., 2008 - Interpretation of the MRS measurements in rocks with high electrical conductivity. Journal of Applied Geophysics, 66 (3-4): 118-127.

https://doi.org/10.1016/j.jappgeo.2008.04.002

Legchenko A., Ezersky M., Camerlynck C. Al-ZoubiA., Chalikakis K. \& Girard J-F., 2008 - Locating waterfilled karst caverns and estimating their volume using magnetic resonance soundings. Geophysics, 73 (5): G51-G61.

https://doi.org/10.1190/1.2958007

Legchenko A., M. Ezersky M. Boucher M., Camerlynck C., Al-Zoubi A. \& Chalikakis K., 2008 - Pre-existing caverns in salt formations could be the major cause of sinkhole hazards along the coast of the Dead Sea. Geophysical Research Letters, 35: L19404.

https://doi.org/10.1029/2008GL035510

Legchenko A., Ezersky M., Kamerlynck C., Al-Zoubi A. $\&$ Chalikakis K., 2009 - Joint use of TEM and MRS method in complex geological setting. Comptes Rendus Geosciences, 341 (10-11): 908-917.

https://doi.org/10.1016/j.crte.2009.07.013

Legchenko A., Descloitres M., Vincent C., Guyard H., Garambois S., Chalikakis K. \& Ezersky M., 2011 Three-dimensional magnetic resonance imaging for groundwater. New Journal of Physics, 13: 025022. https://doi.org/10.1088/1367-2630/13/2/025022

Livne E., 2012 - Evaluation of the Liquefaction Potential along the Dead-Sea Western Shores - Regional Screening and Geotechnical Analysis of Two Boreholes. Unpublished SM Thesis. Ben Gurion University of the Negev, 118 p.

Lucha P., Cardona F., Gutiérrez F. \& Guerrero J., 2008 Natural and human-induced dissolution and subsidence processes in the salt outcrop of the Cardona Diapir (NE Spain). Environmental Geology, 53 (5): 1023-1035. https://doi.org/10.1007/s00254-007-0729-3

Maimon O., Lyakhovsky V., Agnon A. \& Abelson M., 2005 - Stability of cavities and formation of sinkholes along the Dead Sea coast. Geological Survey of Israel Report GSI/19/05, Jerusalem, 65 p. (in Hebrew).

Mahasneh B.Z., 2004 - Dead Sea water as a soil improvement agent. Electronic Journal of Geotechnical Engineering, 9: 1. 
Milanović P.T., 1981 - Karst hydrogeology. Water Resource Publications. Littleton, Colorado, USA.

Milanović P.T., 2000 - Geological engineering in karst: dams, reservoirs, grouting, groundwater protection, water tapping, tunneling. Zebra Publishing, Belgrade, 347 p.

Miller R.D., Xia J., Park C.B. \& Ivanov J.M., 1999 Multichannel analysis of surface waves to map bedrock. The Leading Edge, 18 (12): 1392-1396. https://doi.org/10.1190/1.1438226

Müller-Petke M.,Walbrecker J.O., Knight R., 2013 - The inversion of surface-NMR $\mathrm{T}_{1}$ data for improved aquifer characterization. Geophysics, 78 (6): EN83-EN94. https://doi.org/10.1190/geo2013-0035.1

Palmer D., 1986 - Refraction seismics. The lateral resolution of structure and seismic velocity. Geophysical Press Ltd., London, 269 p.

Parise M., De Waele J. \& Gutiérrez F., 2009 - Current perspectives on the environmental impacts and hazards in karst. Environmental Geology, 58: 235-237. https://doi.org/10.1007/s00254-008-1608-2

Polom U., Bagge M., Wadas S., Winsemann J., Brandes C., Binot F. \& Krawczyk C.M., 2013 - Surveying nearsurface depocentres by means of shear wave seismics. First Break, 31 (8): 67-79.

Polom U., Alrshdan H., Al-Halbouni D., Sawarieh A., Dahm T. \& Krawczyk C.M., 2016 - Improved Dead Sea sinkhole site characterization at Ghor Al Haditha, Jordan, based on repeated shear wave reflection seismic profiling. EGU General Assembly 2016, p. 6440.

Reuter F. \& Stoyan D., 1993 - Sinkholes in carbonate, sulphate, and chloride karst regions: Principles and problems of engineering geological investigations and predictions, with comments for the construction and mining industries. In: Beck B.F. (Ed.), Applied karst geology. Balkema, Rotterdam: 3-25.

Rybakov M., Goldshmidt V., Fleischer L. \& Rotstein Y. 2001 - Cave detection and 4- $d$ monitoring: a microgravity case history near the Dead Sea. The Leading Edge, 20 (8): 896-900.

https://doi.org/10.1190/1.1487303

Rybakov M., Shirman B., Al-Zoubi A. \& Rotshtein Y., 2005

- Cave detection near the Dead Sea - a micromagnetic feasibility study. The Leading Edge, 24 (6): 585-590. https://doi.org/10.1190/1.1946210

Shalev E. \& Lyakhovsky V., 2012 - Viscoelastic damage modeling of sinkhole formation. Journal of Structural Geology, 42: 163-170.

https://doi.org/10.1016/j.jsg.2012.05.010

Shalev E., Lyakhovsky V. \& Yechieli Y. 2006 - Salt dissolution and sinkhole formation along the Dead Sea shore. Journal of Geophysical Research, 111: V03102. https://doi.org/10.1029/2005JB004038

Shamir G., 2006 - The active structure of the Dead Sea depression. Geological Society of America Special Papers, 401: 15-32. https://doi.org/10.1130/2006.2401(02)

Steeples D. \& Miller R.D., 1987 - Direct detection of shallow subsurface voids using high-resolution seismic reflection techniques. In: Beck B.F., Wilson W.L. \& Balkema A.A., (Eds.), Karst hydrogeology: Engineering and environmental applications: 179-183.

Stephens D.B., Hsu K.S., Prieksat M.A., Ankeny M.D., Blanford N., Roth T.L., Kelsey J.A. \& Whitworth J.R., 1998 - A comparison of estimated and calculated effective porosity. Hydrogeology Journal, 6: 156-165. https://doi.org/10.1007/s100400050141
Stein M., Torfstein A., Gavrieli I. \& Yechieli Y., 2010 Abrupt aridities and salt deposition in the post-glacial Dead Sea and its north Atlantic connection. Quaternary Science Reviews, 29: 567-575.

https://doi.org/10.1016/j.quascirev.2009.10.015

Stiller M., Yechieli Y. \& Gavrieli I., 2016 - Rates of halite dissolution in natural brines: Dead Sea solutions as a case study. Chemical Geology, 447: 161-172. https://doi.org/10.1016/j.chemgeo.2016.10.023

Taqieddin S.A., Abderahman N.S. \& Atallah M., 2000 - Sinkhole hazard along the eastern Dead Sea shoreline area, Jordan: a geological and geotechnical consideration. Environmental Geology, 39 (11): 12371253. https://doi.org/10.1007/s002549900095

Wdowinski S., Bock Y., Baer G., Prawirodirdjo L., Bechor N., Naaman S., Knafo R., Forrai Y. \& Melzer Y., 2004 GPS measurements of current crustal movements along the Dead Sea Fault. Journal of Geophysical Research, 109: B05403.

https://doi.org/10.1029/2003JB002640

Van Sambeek L.L., 1996 - Dissolution-induced mine subsidence at the Retsof Salt Mine. In: Solution Mining Research Institute meeting papers. Cleveland, Ohio, October 20-23, 1996, p. 289-309.

Vouillamoz J.M., Legchenko A., Albouy Y., Bakalowicz M., Baltassat J.M. \& Al-Fares W., 2003 - Localization of saturated karst aquifer with magnetic resonance sounding and resistivity imagery. Ground Water, 41 (5): 578-587.

https://doi.org/10.1111/j.1745-6584.2003.tb02396.x

Yechieli Y., 2000 - Fresh-Saline ground water interface in the western Dead Sea area. Ground Water, 38 (4): 615-623.

https://doi.org/10.1111/j.1745-6584.2000.tb00253.x

Yechieli Y., 2007 - Geochemical monitoring of groundwater in boreholes at the Dead Sea coastal area - project of sinkholes. GSI Report TR-GSI/18/2007, 16 p. (inHebrew).

Yechieli Y., Ronen D. \& Berkowitz B., 1995 - Are sedimentary salt layers always impermeable? Geophysical Research Letters, 22 (20): 2761-2764. https://doi.org/10.1029/95GL02785

Yechieli Y., Kafri U, Goldman M. \& Voss C.I., 2001 Factors controlling the configuration of the fresh-saline water interface in the Dead Sea coastal aquifers: synthesis of TDEM surveys and numerical groundwater modeling. Hydrogeology Journal, 9: 367-377. https://doi.org/10.1007/s100400100146

Yechieli Y., Abelson M., Bain A., Shtivelman V., Onn C., Wacks D., Bar G., Kalbo R., Lyachovski V., 2004 - Sinkhole phenomena along the Dead Sea shore line. Report GSI-21/04 (in Hebrew).

Yechieli Y., Abelson M., Bein M., Crouvi O. \& Shtivelman V., 2006 - Sinkhole "swarms" along the Dead Sea coast: reflection of disturbance of lake and adjacent groundwater systems. Geological Society of America Bulletin, 118 (9-10): 1075-1087.

https://doi.org/10.1130/B25880.1

Yechieli Y, Shalev E., Wollman S., Kiro Y. \& Kafri U., 2010 - Response of the Mediterranean and Dead Sea coastal aquifers to sea level variations. Water Resources Research, 46: W12550.

https://doi.org/10.1029/2009WR008708

Yechieli Y., Abelson M. \& Baer G. 2016 - Sinkhole formation and subsidence along the Dead Sea coast, Israel. Hydrogeology Journal, 24 (3): 601-612. https://doi.org/10.1007/s10040-015-1338-y 